TORONTO POLICY AND MISSING MIDDLE HOUSING:

CASE STUDIES FOR POLICY REFORM

\author{
by \\ Brent Kuefler \\ BA, University of Alberta, 2005 \\ MA, Memorial University, 2010 \\ A Major Research Paper \\ presented to Ryerson University \\ in partial fulfilment of the requirements for the degree of \\ Master of Planning \\ In \\ Urban Development
}

Toronto, Ontario, Canada, 2020

(C) Brent Kuefler, 2020 


\section{AUTHOR'S DECLARATION FOR ELECTRONIC SUBMISSION OF A MRP}

I hereby declare that I am the sole author of this MRP. This is a true copy of the MRP, including any required final revisions.

I authorize Ryerson University to lend this MRP to other institutions or individuals for the purpose of scholarly research.

I further authorize Ryerson University to reproduce this MRP by photocopying or by other means, in total or in part, at the request of other institutions or individuals for the purpose of scholarly research.

I understand that my MRP may be made electronically available to the public. 


\title{
TORONTO POLICY AND MISSING MIDDLE HOUSING: CASE STUDIES FOR POLICY REFORM
}

\author{
(C)Brent Kuefler, 2020 \\ Master of Planning \\ In \\ Urban Development \\ Ryerson University
}

\section{ABSTRACT}

This paper examines how the Toronto Official Plan and zoning bylaw have limit the market from effectively responding to housing demand. These documents protect Toronto's 'stable' neighbourhoods from increased density and restrict development of affordable missing middle housing forms which could provide ground-related housing in desired areas. Policy which limits housing options in existing communities has contributed to negative social, economic, and environmental outcomes within cities.

Recognizing the negative impacts of exclusionary zoning, jurisdictions across North America are reforming policy and zoning bylaws to permit multi-unit housing in areas zoned for single-detached housing. This paper reviews reform processes in several jurisdictions and recommends that Toronto reform its Official Plan and zoning bylaw to permit increased housing options across the city, conduct outreach to change opinions on increased density, incentivize production of missing middle housing, and use land value capture tools to limit increases in land values brought about by rezoning.

\section{KEYWORDS}

missing middle housing, yellowbelt, stable neighbourhoods, Toronto, zoning 


\section{ACKNOWLEDGEMENTS}

First, I would like to thank my supervisor, David Amborski, for his guidance, advice, and support through this research.

Thank you also to Diana Petramala for her insightful commentary and feedback on my paper. It was very appreciated and helped me improve the clarity and precision of the arguments presented here.

Finally, thank you to Ryerson's School of Urban and Regional Planning for the opportunity to further my education and for providing the inspiration to pursue this research. 


\section{TABLE OF Contents}

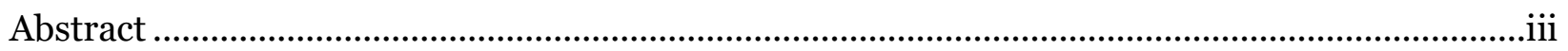

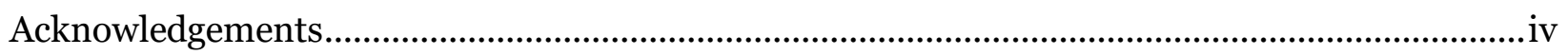

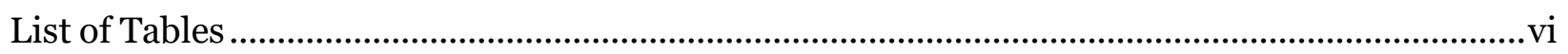

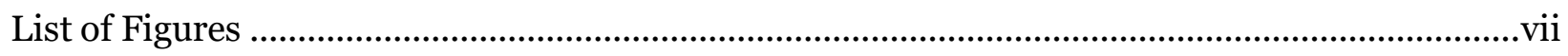

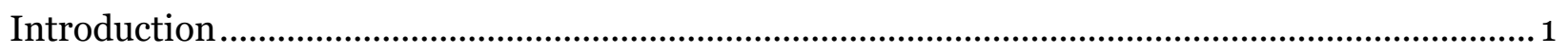

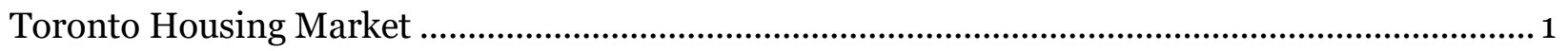

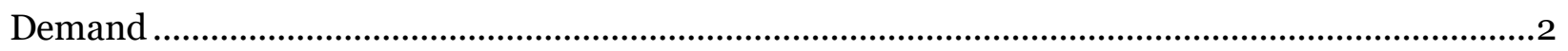

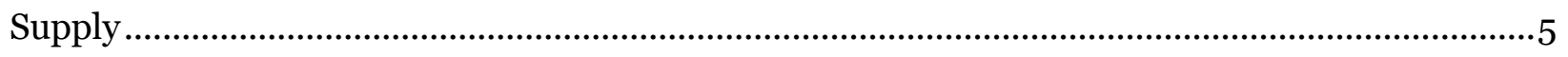

The Monocentric Model and Economic Theories of Urban Growth ............................................6

Economic Theory and Housing Development in Toronto ...............................................................

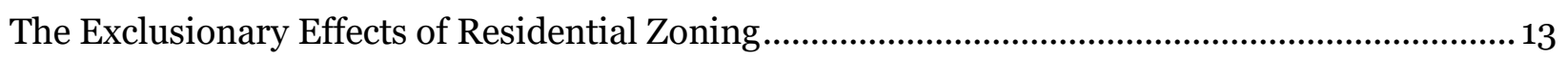

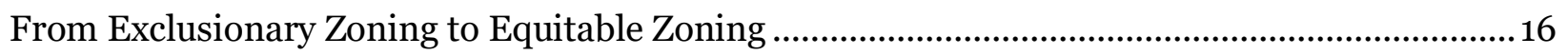

Critiques of Zoning Reform to Increase Housing Supply ........................................................... 18

Case Study: California's Failed Attempts at Statewide Zoning Reform.......................................21

Case Study: Portland's Residential Infill Project...........................................................................25

Case Study: Minneapolis 2040 .................................................................................................... 30

Case Study: Seattle's Mandatory Housing Affordability and Neighbourhoods for All..................33

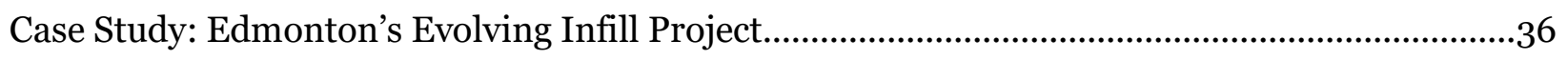

Case Study: Vancouver's Norquay Village ................................................................................... 40

Lessons for Toronto from the Case Studies ............................................................................42

Recommendations for Toronto ...........................................................................................4

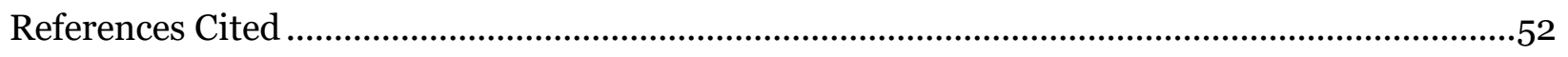




\section{LIST OF TABLES}

Table 1: Toronto Observed and Projected Population, 1996-2041 ….............................................2

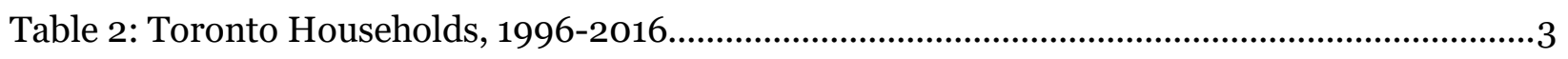

Table 3: Housing Preference by Generation ....................................................................................

Table 4: Housing Completions in the GTA, 2012-2018 …............................................................

Table 5: Residential Zones in Toronto ..........................................................................................11

Table 6: Permitted Housing Forms in Residential Zones..............................................................11

Table 7: SB 50 Equitable Communities Incentive........................................................................23

Table 8: Proposed maximum building sizes using FAR .......................................................... 28

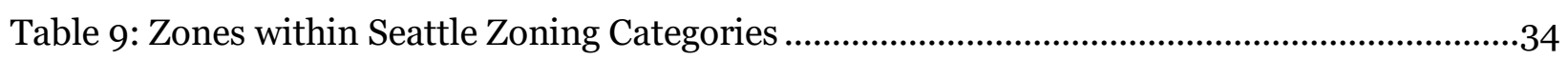

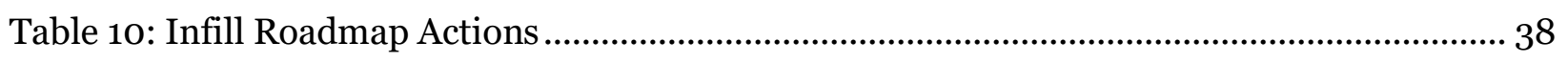

Table 11: Norquay Village Proposed Residential Zoning ............................................................ 41

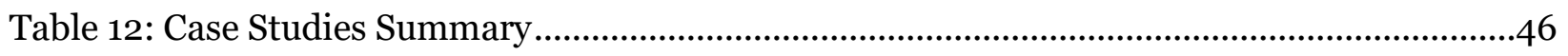




\section{LIST OF FIGURES}

Figure 1: Housing Completions by Census Tract, 2012-2018..................................................6

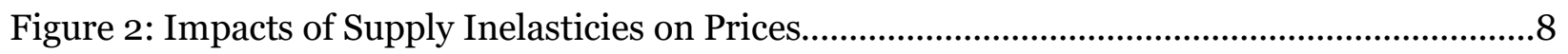

Figure 3: Missing middle housing forms …............................................................................... 17 


\section{INTRODUCTION}

Housing within the City of Toronto is becoming increasingly unaffordable. The "major expression of housing affordability is not homelessness, but an inability to afford adequate housing in an area where one's needs are met" (Levine, 2006: 83). This statement points to the importance of a city providing a diverse housing stock with a range of housing forms, at various levels of affordability, and dispersed throughout the city. However, land use policies restrict development of housing that would meet the needs and preferences of many people in the city.

This paper explores the current Toronto housing market and shows how supply is not meeting demand and is resulting in rising housing costs for new households. An important barrier to constructing new housing supply in Toronto is its current Official Plan and zoning bylaw which prevents development in 'stable' neighbourhoods and limits much of its residential neighbourhoods to single-detached housing.

This policy direction is contrary to economic theory, which posits that when increased demand for housing in a location drives land values higher, the market responds by producing smaller and less expensive housing units. Municipalities across North America are acknowledging the impacts that their land use policies are having on their housing market. These policies are often rooted in a historical desire for exclusion from communities on race and class lines. This paper examines the historical and political drivers of zoning bylaws that have shaped Toronto's housing market and contributed to its affordability challenges. This report then examines case studies from California, Portland, Minneapolis, Seattle, Edmonton, and Vancouver, where zoning reform, with the goal of increasing the supply of increasing the supply of missing middle housing, was successfully or unsuccessfully undertaken. Finally, lessons from these case studies are used to generate recommendations that the City of Toronto can use to successfully modernize its zoning bylaws so that they can help encourage a more diverse and affordable housing stock.

\section{TORONTO HOUSING MARKET}

Home ownership is becoming increasingly expensive in Toronto. Between May 2006 and May 2016, the composite home ownership price in the GTA increased from $\$ 331,900$ to $\$ 634,400$, a 91\% increase (Canadian Real Estate Association, n.d.). By February 2020 this price further increased to \$846,100, a 155\% from May 2006 (Canadian Real Estate Association, n.d.). The increase in home ownership prices has far outpaced the increase in household incomes in the Toronto area. Between 2006 and 2016 median household incomes increased by 22\% in the Toronto CMA and 25\% in the City of Toronto (Statistics Canada, 2007; 2017). A study by the 
Centre for Urban Research and Land Development (Clayton and Petramala, 2019: 15) finds that the average household would have to devote $91.3 \%$ of its income to afford a mortgage on an average priced single detached home. The same average household would have to devote $47 \%$ of its income to afford an average priced condominium apartment in the GTA (Clayton and Petramala, 2019: 15). These values are far in excess of the $30 \%$ shelter cost to income ratio used by the CMHC to define housing affordability (CMHC, 2019).

Despite the immense construction Toronto is experiencing, there is a mismatch between supply and demand within the Toronto housing market (Clayton and Petramala, 2019; Lorinc et al., 2019). The next sections will provide an overview of the factors shaping housing demand and supply within Toronto.

\section{DEMAND}

Increasing housing demand in Toronto is shaped by four main factors. The first is population increase - with more people there is more demand for housing. Toronto's population is growing, and all forecasts indicate that this will continue to be the case to 2041 (Table 1). The range in population projections for Toronto show that while Toronto's population will increase, the extent of the population increase is uncertain. Therefore, it is incumbent for the city to ensure that its housing market can respond quickly and efficiently to changes in population trends to ensure adequate housing is available. Toronto is currently unable to meet demand for housing. If Toronto's population growth rate accelerates as predicted by the Ministry of Finance (1.74\%), Toronto will become ever harder pressed to provide a housing supply that meets demand. Toronto must find ways to increase its ability to provide housing to its increasing population or its residents will be increasingly under housed and paying increasing amounts of their incomes for this housing.

\begin{tabular}{|c|c|c|c|c|c|c|c|c|c|c|}
\hline & & \multicolumn{3}{|c|}{ Toronto Total Population* } & \multicolumn{3}{|c|}{ Ministry of Finance } & \multicolumn{3}{|c|}{ Growth Plan } \\
\hline & & $\begin{array}{c}\text { Population } \\
\text { Growth }\end{array}$ & $\begin{array}{l}\text { Percent } \\
\text { Growth }\end{array}$ & $\begin{array}{c}\text { Average } \\
\text { Annual } \\
\text { Growth }\end{array}$ & $\begin{array}{l}\text { Population } \\
\text { Growth** }\end{array}$ & $\begin{array}{l}\text { Percent } \\
\text { Growth }\end{array}$ & $\begin{array}{c}\text { Average } \\
\text { Annual } \\
\text { Growth }\end{array}$ & $\begin{array}{l}\text { Population } \\
\text { Growth** }\end{array}$ & $\begin{array}{l}\text { Percent } \\
\text { Growth }\end{array}$ & $\begin{array}{c}\text { Average } \\
\text { Annual } \\
\text { Growth }\end{array}$ \\
\hline \multirow{4}{*}{ Census Data } & $1996-2000$ & 127,145 & $5.18 \%$ & $1.04 \%$ & & & & & & \\
\hline & $2001-2005$ & 22,648 & $0.88 \%$ & $0.18 \%$ & & & & & & \\
\hline & $2006-2010$ & 90,998 & $3.50 \%$ & $0.70 \%$ & & & & & & \\
\hline & 2011-2015 & 117,097 & $4.35 \%$ & $0.87 \%$ & & & & & & \\
\hline \multirow{4}{*}{ Projections } & $2016-2021$ & & & & 372,009 & $13.24 \%$ & $2.65 \%$ & & & \\
\hline & $2016-2031$ & & & & 787,424 & $28.02 \%$ & $1.87 \%$ & 379,742 & $13.51 \%$ & $0.90 \%$ \\
\hline & $2031-2041$ & & & & 431,954 & $12.01 \%$ & $1.20 \%$ & 210,000 & $6.58 \%$ & $0.66 \%$ \\
\hline & 2016-2041 & & & & $1,219,378$ & $43.39 \%$ & $1.74 \%$ & 589,742 & $20.99 \%$ & $0.84 \%$ \\
\hline
\end{tabular}

*includes census undercoverage

**uses Toronto Total Population for 2016 population

Table 1: Toronto Observed and Projected Population, 1996-2041 (Statistics Canada, n.d., 2007, 2012, 2017; Ontario Ministry of Finance, 2019; Ontario, 2019) 
The second factor in driving housing demand within Toronto is changing demographics and reduced household sizes (Table 2). Over the 20 years from 1996 to 2016, average household size in Toronto declined by over 7\% (Statistics Canada, n.d., 2007, 2012, 2017). This results in the need for more housing units to house the same number of people (Hertel and Scorgie 2019: 80). The Canadian Centre for Economic Analysis projects the number of households within Toronto will increase by 32.5\% by 2041 (2019: 6). A growing population and declining household sizes are not the only factors that will contribute to increasing number of households needing to be housed in Toronto in the future. The millennial generation, those born between 1981 and 1996, are living with their parents longer or living with roommates and delaying the creation of their own households and families. The delay in creating their own household is largely influenced by low

\begin{tabular}{|l|ccc|}
\cline { 2 - 4 } \multicolumn{1}{c|}{} & $\begin{array}{c}\text { Average number of } \\
\text { persons in private } \\
\text { households }\end{array}$ & $\begin{array}{c}\text { Number of } \\
\text { Households }\end{array}$ & $\begin{array}{c}\text { Toronto } \\
\text { Census } \\
\text { Population }\end{array}$ \\
\hline 1996 & 2.6 & 903,585 & $2,385,421$ \\
2001 & 2.6 & 943,080 & $2,481,494$ \\
2006 & 2.5 & 979,440 & $2,503,281$ \\
2011 & 2.5 & $1,046,875$ & $2,615,060$ \\
2016 & 2.4 & $1,112,930$ & $2,731,571$ \\
\hline Change 1996- & $-7.69 \%$ & $23.17 \%$ & $14.51 \%$ \\
2016 & & & \\
\hline
\end{tabular}

Table 2: Toronto Households, 1996-2016 (Statistics Canada, n.d., 2007, 2012, 2017)

The third factor shaping housing demand in Toronto is income. While population, changing demographics and household size all point to greater need for housing, the ability of a household to purchase and consume housing is constrained by their ability to afford it. Thus, it is important to recognize that final housing demand is subject to effective demand - the amount of a commodity that can be consumed at a price (Fisher et al., 1949). Effective demand is shaped by unemployment rates, types of jobs available in an economy, and wages. As prices for owning homes increase without a concomitant increase in household incomes, more households will be unable to afford home ownership and will be directed to the rental submarket. This has the effect of increasing demand for rental units, increasing costs of renting, and contributing to unaffordable housing prices in this submarket. However, if an individual household's real income 
increases, it can consider changing the housing it consumes and purchase housing that reflects their personal preferences.

Housing preference is the fourth factor shaping demand within Toronto's housing market. There is a strong preference for ground-related housing (single-detached, semi-detached, or townhouse) within Toronto (Clayton and Irish, 2017; Clayton and Petramala, 2019: 13-14; Hertel and Scorgie, 2019: 80). A review of surveys examining housing preference amongst homebuyers and potential homebuyers found an overwhelming preference for ground-related housing in the city with nearly two-thirds of potential homebuyers preferring ground-related housing. When examining housing preferences of potential home buyers by generation (Table 3 ), there is a strong preference for ground-related housing amongst all age cohorts (Clayton and Irish, 2017).

\begin{tabular}{|l|cccc|cc|}
\hline Generation & $\begin{array}{c}\text { Single- } \\
\text { detached }\end{array}$ & $\begin{array}{c}\text { Semi- } \\
\text { detached }\end{array}$ & Townhouse & $\begin{array}{c}\text { Total } \\
\text { Ground- } \\
\text { related }\end{array}$ & $\begin{array}{c}\text { Condominium } \\
\text { Apartment }\end{array}$ & Other \\
\hline "Millennials" & $38 \%$ & $12 \%$ & $20 \%$ & $70 \%$ & $28 \%$ & $3 \%$ \\
"X" & $52 \%$ & $16 \%$ & $16 \%$ & $\mathbf{8 4 \%}$ & $17 \%$ & $1 \%$ \\
"Boomers" & $56 \%$ & $5 \%$ & $8 \%$ & $69 \%$ & $29 \%$ & $2 \%$ \\
\hline
\end{tabular}

Table 3: Housing Preference by Generation (Clayton and Irish, 2017)

Millennials currently represent a large, age cohort in the Greater Toronto Area (Petramala and Clayton 2018: 5). While millennials are delaying the formation of their own households, this generation is not unique from older generations in their preferences in terms of tenure, location, and housing form. As Millennials form their own households and start families, and as their income potential increases, they will increasingly desire to own ground-related forms of housing (Petramala and Clayton, 2018). This will increase demand for the stock of ground-related housing in Toronto, which will require an adequate supply of available housing forms. One way this could occur is through existing owners of ground-related housing 'downsizing' into apartment units as they age. However, it is expected that households will not do this until the age of 85 and therefore this will not provide a significant supply of housing onto the market until between 2040 and 2050. Thus, ground-oriented housing supply will have to come from the new housing market (Petramala and Clayton, 2018: 12).

Housing demand in Toronto is driven by four factors: population, household formation, income, and preferences. Toronto will see significant population growth to 2041. This, along with declining household sizes and Millennials seeking to form their own households, will increase housing demand. However, in order to meet demand, there must be an understanding of the amount and type (based on household incomes and housing preferences) of supply needed. There 
is a strong preference for ground-oriented housing units in Toronto. This will likely increase as Millennials' income potentials increase and they start forming their own households and families.

\section{SUPPLY}

In the previous section, it was showed that housing demand is shaped by population increase, household size, income, and preferences. Thus, the housing market should respond to this and produce a sufficient quantity of housing units at prices and quality that is amenable to residents. This section will examine the housing that is being produced in Toronto in the context of the previously described demand.

Despite the preference for ground related housing, the production of these forms of housing is declining in Toronto. In 2018 apartment unit starts surpassed the combined number of single-detached, semi-detached, and townhouse starts (Clayton and Petramala, 2019: 9). Between 2007 and 2017, there were 161,161 housing completions in Toronto. Of these, 81.5\% were for the condo market, $\mathbf{1 1 . 2 \%}$ were for the ownership market, and 7.2\% were purpose-built rentals (Canadian Centre for Economic Analysis 2019: 45). CMHC (n.d.) data reveals that between 2012 and 2018, nearly 90\% of unit completions within Toronto were apartment units. While it is expected that smaller units will be produced as land values increase, it is surprising that smaller, ground-related housing units, such as semi-detached or row houses, are not being produced since these would be a better substitute for consumers who prefer single-detached housing (Clayton and Petramala, 2019: 9). On a regional scale, much more ground-related housing is being produced, from about two-thirds of all units in York Region to over 88\% of units in Durham Region (Table 4).

\begin{tabular}{|c|c|c|c|c|c|c|c|c|c|c|c|}
\hline \multirow[b]{2}{*}{ Region } & \multicolumn{2}{|c|}{$\begin{array}{c}\text { Single-Detached } \\
\text { Houses }\end{array}$} & \multicolumn{2}{|c|}{ Semi-Detached Houses } & \multicolumn{2}{|c|}{ Row Houses } & \multicolumn{2}{|c|}{$\begin{array}{c}\text { Total Ground-related } \\
\text { Units }\end{array}$} & \multicolumn{2}{|c|}{ Apartment Units } & \multirow{2}{*}{\begin{tabular}{|c} 
Total \\
Completions \\
$\begin{array}{c}\text { Number of } \\
\text { Units }\end{array}$ \\
\end{tabular}} \\
\hline & $\begin{array}{c}\text { Number of } \\
\text { Units }\end{array}$ & $\begin{array}{c}\text { Percentage } \\
\text { of Units }\end{array}$ & $\begin{array}{l}\text { Number } \\
\text { of Units }\end{array}$ & $\begin{array}{c}\text { Percentage } \\
\text { of Units }\end{array}$ & $\begin{array}{c}\text { Number of } \\
\text { Units }\end{array}$ & $\begin{array}{c}\text { Percentage } \\
\text { of Units }\end{array}$ & \begin{tabular}{|c|}
$\begin{array}{c}\text { Number of } \\
\text { Units }\end{array}$ \\
\end{tabular} & $\begin{array}{c}\text { Percentage } \\
\text { of Units }\end{array}$ & $\begin{array}{c}\text { Number of } \\
\text { Units }\end{array}$ & $\begin{array}{c}\text { Percentage } \\
\text { of Units }\end{array}$ & \\
\hline Durham* & 3,711 & $53.1 \%$ & 384 & $5.5 \%$ & 2,075 & $29.7 \%$ & 6,170 & $88.3 \%$ & 820 & $11.7 \%$ & 6,990 \\
\hline York & 22,687 & $41.2 \%$ & 2,330 & $4.2 \%$ & 10,928 & $19.9 \%$ & 35,945 & $65.3 \%$ & 19,105 & $34.7 \%$ & 55,050 \\
\hline Peel & 20,508 & $46.7 \%$ & 5,589 & $12.7 \%$ & 8,148 & $18.6 \%$ & 34,245 & $78.0 \%$ & 9,678 & $22.0 \%$ & 43,923 \\
\hline Halton** & 8,114 & $37.6 \%$ & 890 & $4.1 \%$ & 6,647 & $30.8 \%$ & 15,651 & $72.4 \%$ & 5,952 & $27.6 \%$ & 21,603 \\
\hline Toronto & 7,892 & $6.9 \%$ & 984 & $0.9 \%$ & 3,540 & $3.1 \%$ & 12,416 & $10.8 \%$ & 102,184 & $89.2 \%$ & 114,601 \\
\hline GTA Total & 62,912 & $26.0 \%$ & 10,177 & $4.2 \%$ & 31,338 & $12.9 \%$ & 104,427 & $43.1 \%$ & 137,739 & $56.9 \%$ & 242,167 \\
\hline
\end{tabular}

The distribution of housing development in Toronto is uneven and heavily concentrated in several areas. As shown by Figure 1, most housing development is located downtown. Other areas seeing significant housing growth include Etobicoke, Midtown, and North York, and north 
of Highway 401. Most significant is the vast proportion of Toronto that is seeing very little new housing construction.

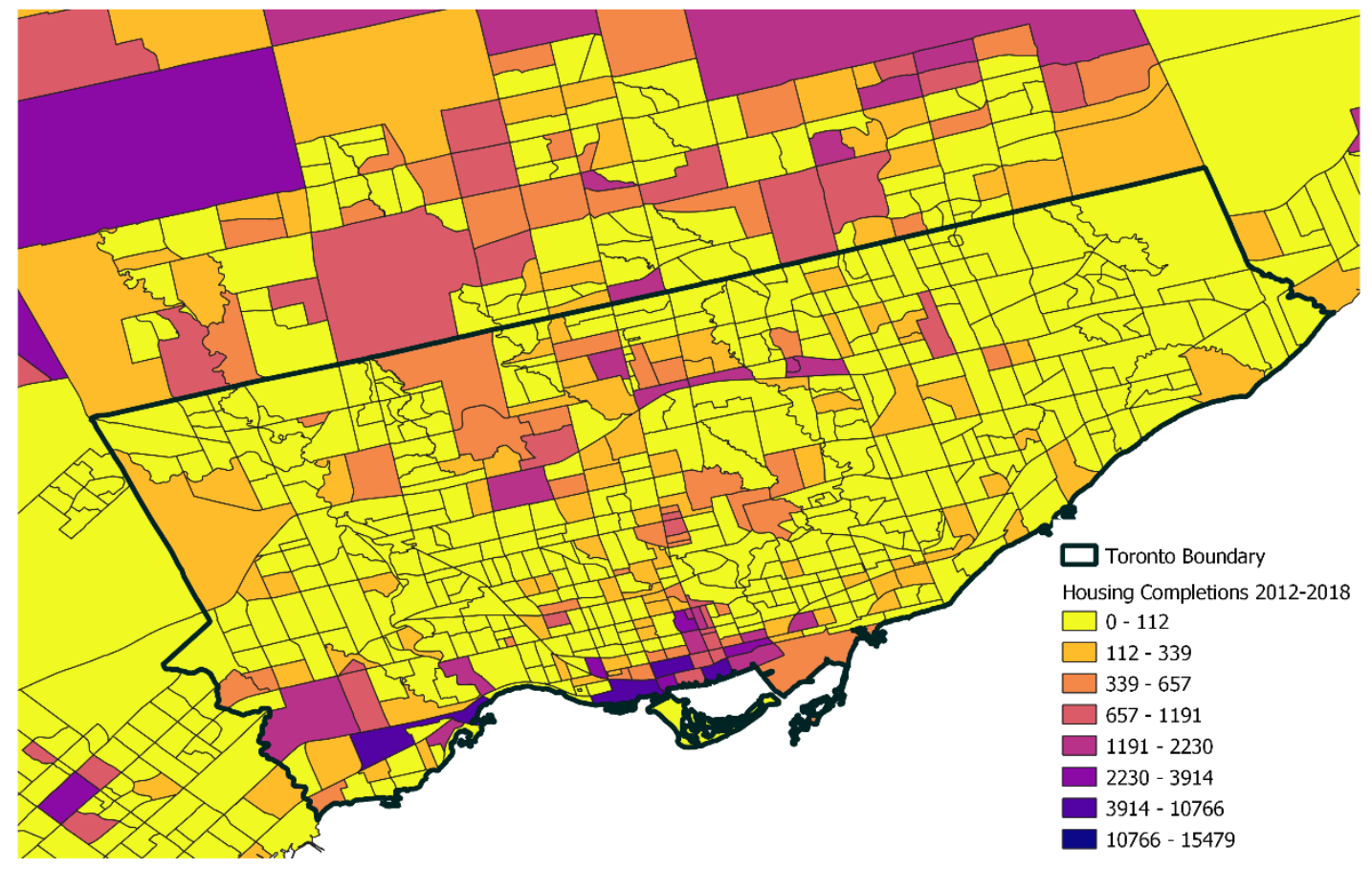

Figure 1: Housing Completions by Census Tract, 2012-2018 (CMHC, n.d.)

The supply of housing that is being produced in Toronto does not meet the demand of its residents. An implication of this mismatch between supply and demand is that ground-oriented housing will continue to become increasingly expensive and the neighbourhoods dominated by these housing forms will become increasingly exclusive. Anyone who is unable to afford to live in this preferred housing form will be clustered into the areas that are seeing heavy development of apartment units. The next section of this paper will examine economic theories of urban growth and how land use regulations shape the urban form and contribute to housing affordability.

\section{The Monocentric Model and ECONOMic TheORIES OF URBan GROWTH}

The monocentric city model is a simple mathematical model, developed in the 1960s, that allows economists and planners to study the spatial structure of cities and to understand the relationships between housing demand, housing supply, and land values. This model suggests that density within a city will decrease as one moves away from the central business district (CBD) due to decreasing land values. Near the city core and its concentration of jobs, high land values 
will result in smaller housing units being created in taller buildings; in suburban areas that are distant from the job rich CBD, the model predicts that lower land prices result in low density, low rise, single family units being built. While a housing consumer can consume more housing or spend less on housing in a neighbourhood that is distant from the CBD, these benefits are offset by increased time and transportation costs needed to reach jobs. On the other hand, people who choose to live near the CBD have faster and less expensive commutes but must occupy less housing and pay more per square foot of housing (Bertaud, 2018; Bruekner, 2011).

This model does not assume a static city and allows for predictions of how the urban structure would change over time in response to increasing demand for housing. As a city's population increases and demand for housing exceeds the housing supply, excess demand drives up the price of housing across the city. Housing consumers choose to live in smaller units that cost less. Housing producers, who see their profits increase in this market, can aggressively compete to acquire land which drives up land values. To compensate for increased land values and to allow housing developments to remain profitable, developers must fit more housing units onto a fixed parcel size. This results in buildings being constructed higher and smaller units being built. Ultimately, increased consumer demand for housing is met through the (long-term) rebuilding of the city with increased density and smaller housing units (Bruekner, 2011: 44).

This model assumes that housing and land supply are unconstrained by land use regulations and developers are free to build in the way predicted by this model. However, all cities have some form of land use regulations that restrict land use, contribute to increased land prices, limit and shape the housing market, and constrain development response to increased housing demand.

Glaeser and Gyourko (2002) consider housing affordability from the perspective of housing prices vis-à-vis housing construction costs and find in many cities housing prices are close to the cost of construction. However, some cities have home prices that are significantly higher than what would be expected from construction costs. Using classical economics and the monocentric model, this phenomenon would be explained by demand for housing in certain areas driving up the values of a limited land supply. As the value of land rises, so do the values of the homes that are sited on the land. However, using a hedonic model they find that housing costs are similar irrespective of lot size (e.g. more land is not increasing the housing cost) and that high housing costs are not often associated with significant increases in density. They propose the alternative explanation that housing is expensive not because of a constrained land supply, but because of land use regulations that artificially limit land supply, increase land prices, and limit 
construction and the ability of the housing market to respond to demand (Glaeser and Gyourko, 2002: 4-5).

Regulations alone are not a primary contributor to housing supply elasticities and the ability of the market to respond to upward shifts in housing prices. Supply inelasticity is a function of both geographic land constraints and land use regulations (Saiz, 2010). Most areas that appear to be supply inelastic are heavily constrained by geography, such as water, slopes, or mountains (Saiz, 2010: 1254). These areas have less developable land and during a demand shock are less able to respond with increased housing supply (Saiz, 2010: 1264). Thus, as demand for housing increases, so do prices. Furthermore, cities with physical land supply constraints tend to have high land values and adopt strong anti-growth regulations to protect these land values (Saiz, 2010: 1257, 1286). This further contributes to housing supply inelasticity.

The elasticity or inelasticity of a market's housing supply will determine what happens when faced with an increase in housing demand. Either housing prices can increase, or housing quantities increase (Glaeser et al., 2006: 72). In a city that has an elastic housing supply, new housing will be able to be produced at a rate that is reflective of shifts in demand. The new housing supply that is created in response to demand will moderate housing price increases and housing

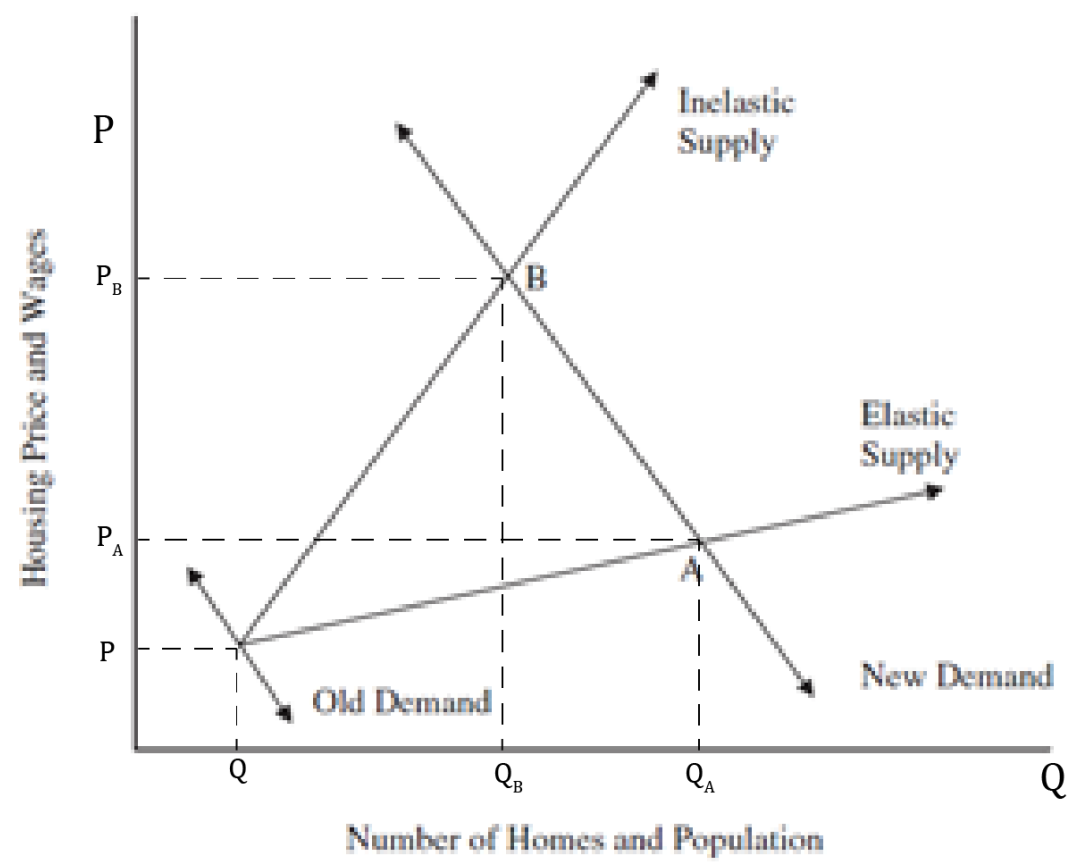

Figure 2: Impacts of Supply Inelasticity on Prices (Glaeser et al., 2006: 72, equilibrium lines added by author) 
prices should not rise much above construction costs (Glaeser et al., 2006: 72). However, in housing markets with an inelastic housing supply, the needed number of housing units will not be produced, and housing prices will increase significantly (Figure 2).

Through imposing land use controls that seek to limit and direct development, municipalities in turn impact the housing market. By limiting what can be built and where, these regulations create an inelastic housing supply (Glaeser et al., 2006: 73) that tends to increase housing prices and land values (Glaeser and Gyourko, 2002) and cause exclusionary effects within the city (Levine 2006: 52).

When land supply is constrained, such as when land use policies limit residential development, this market process cannot function. As demand for housing in neighbourhoods that are close to jobs and amenities increase, developers are unable to respond to the demand for housing by developing smaller units in these areas. Housing costs thereby increase and those who cannot afford these higher costs are excluded from the neighbourhood. Land use controls which limit growth in mature neighbourhoods force residential development into small enclaves in which higher density development is permitted or to the fringes of the city which may be distant from jobs and have poor transportation options (Levine, 2006: 132).

\section{ECONOMic Theory AND Housing DeVELOPMENT in TORONTO}

As shown in Figure 1 the pattern of housing development within Toronto over the last several years has not coincided with predicted growth patterns established by economic theory. The city is seeing extremely large housing growth centred on the downtown and the CBD. However, there is very little housing growth in the census tracts closest to the downtown, where economic theory suggests increasing land values would precipitate housing construction to produce smaller, more affordable units. There is more housing growth north of the downtown near the Yonge and Eglinton, north of Highway 401, and in Etobicoke. As well, as established earlier in this paper, there exists strong demand for ground related housing that is not being produced. As suggested by economists who look at the impacts of regulations on the development of housing supply, an answer to these contradictions can be provided through an examination of Toronto's land use regulations - particularly its Official Plan (OP) and Zoning Bylaw (ZBL). Toronto is a city that is geographically bounded by Lake Ontario and the regions of Peel, York, and Durham and, as noted by Saiz (2010), cities which have constraints on land supply tend to have higher land values and strict land use regulations. This is the case with Toronto. 
Toronto's Official Plan and zoning restricts housing forms that can be built in much of Toronto (Clayton and Petramala 2019: 19; Hertel and Scorgie 2019: 79). Toronto seeks to protect its 'stable' neighbourhoods by limiting development and intensification within them to preserve their character. This is explicitly stated in Chapter 4 of the City of Toronto's Official Plan (2015):

Many zoning by-laws currently permit only single detached houses. The type of dwellings permitted varies among geographic neighbourhoods and these detailed residential use lists are contained in the established zoning by-laws, which will remain in place and establish the benchmark for what is to be permitted in the future. If, for example, an existing zoning by-law permits only single detached houses in a particular geographic neighbourhood and the prevailing building type in that neighbourhood is single detached dwellings, then the Plan's policies are to be interpreted to allow only single detached dwellings in order to respect and reinforce the established physical character of the neighbourhood (Section 4-5).

Neighbourhoods are the:

low rise and low density residential areas that are considered to be physically stable. Development in Neighbourhoods will be consistent with this objective and will respect and reinforce the existing physical character of buildings, streetscapes and open space patterns in these areas (Section 2-28).

The idea that low-density neighbourhoods need protection from increased density began in the early $20^{\text {th }}$ century. Apartments, at this time, were considered "unhealthy, immoral, and corrosive to the ideal home and household structure" (Meslin, 2019: 64). Living in an apartment was believed to lead to women being idle and caused marriages to breakdown. In 1912 apartments were prohibited from residential streets (Meslin, 2019: 64; White, 2019: 30). The 1960s were a time of uncertainty with urban renewal, transit and highway construction, and gentrification threatening to change low-rise neighbourhoods. Planners decided that these neighbourhoods should be considered 'stable' and protected from development that would change their character (Meslin, 2019, 64). Toronto's OP approved in 1968 established a three-part residential classification system: stable areas of low-density; areas where high-density apartments were permitted; and improvement areas (White, 2019: 33-34). The stable areas were to be "regarded as inviolate, and a firm commitment made that no basic changes through zoning or other public action which is not in keeping with the character of the area will be allowed for a period of ten years" (White, 2019: 33). This bias towards protecting low-density residential neighbourhoods from higher-density forms of residential use continued across the decades and remained in the amalgamated City of Toronto's later OP (Meslin, 2019: 65). The protection of stable neighbourhoods through the OP was enshrined by Official Plan Amendment (OPA) 320 which introduced the requirement that development in these neighbourhoods respect the 'prevailing character' and 'prevailing building types' that currently exist (Scorgie, 2019). This has enabled 
City staff to reject development applications because the proposed built form does not coincide with the prevailing built form even though zoning permits the use. For example, City staff, on February 11, 2019, recommended the Committee of Adjustment reject a proposal to construct a triplex at 54 Westhampton Drive stating:

Although a triplex is a permitted building type within the RM zone, there are no other triplexes on Westhampton Drive, or within the same zone as the subject property. All the other lots on the street and within the subject RM zone are onestorey single detached dwellings. In this regard, it is Planning Staff's opinion a triplex would not be consistent with the established character of the Neighbourhood, and that the subject lot in its current form maintains and reinforces the physical character of the Neighbourhood. Staff note that on the street, only one other Minor Variance application has been considered by the Committee of Adjustment, which signifies that the Neighbourhood is stable (Cresswell, 2019).

Nearly $51 \%$ of Toronto's land area is zoned for a primary residential use (Table 5). The broad "Residential Zones" category consists of the residential uses that are associated with the Neighbourhoods classification in the OP. The dominant residential zone is the RD zone which comprises over $60 \%$ of all residentially zoned land in Toronto and over $30 \%$ of the entire land area of the city. This is the most restrictive residential zone in Toronto, permitting only single-

\begin{tabular}{|c|c|c|c|c|}
\hline & Zone & Area $\left(m^{2}\right)$ & $\begin{array}{c}\% \text { of Residential } \\
\text { Areas }\end{array}$ & $\begin{array}{c}\% \text { of Toronto } \\
\text { Area }\end{array}$ \\
\hline \multirow{5}{*}{ Residential Zones } & Residential (R) & $42,214,208.67$ & $13.1 \%$ & $6.7 \%$ \\
\hline & Residential Townhouse (RT) & $9,509,051.00$ & $3.0 \%$ & $1.5 \%$ \\
\hline & Residential Detached (RD) & $200,514,027.18$ & $62.3 \%$ & $31.6 \%$ \\
\hline & Residential Semi-detached (RS) & $13,548,928.54$ & $4.2 \%$ & $2.1 \%$ \\
\hline & Residential Multiple (RM) & $34,848,231.24$ & $10.8 \%$ & $5.5 \%$ \\
\hline \multirow{3}{*}{$\begin{array}{c}\text { Residential } \\
\text { Apartment Zones }\end{array}$} & Residential Apartment (RA) & $13,711,470.23$ & $4.3 \%$ & $2.2 \%$ \\
\hline & Residential Apartment-Commercial (RAC) & $7,271,051.40$ & $2.3 \%$ & $1.1 \%$ \\
\hline & Total Residential & $321,616,968.26$ & $100.0 \%$ & $50.7 \%$ \\
\hline
\end{tabular}

Table 5: Residential Zones in Toronto (City of Toronto, n.d.)

\begin{tabular}{|c|c|c|c|c|c|c|c|c|}
\hline & \multirow[b]{2}{*}{ Zone } & \multicolumn{7}{|c|}{ Housing Permitted } \\
\hline & & $\begin{array}{l}\text { Single- } \\
\text { Detached }\end{array}$ & $\begin{array}{c}\text { Semi- } \\
\text { Detached }\end{array}$ & Townhouses & Duplexes & Triplexes & Fourplexes & $\begin{array}{l}\text { Apartment } \\
\text { Buildings }\end{array}$ \\
\hline \multirow{5}{*}{$\begin{array}{l}\text { Residential Zone } \\
\text { Category }\end{array}$} & Residential (R) & $\checkmark$ & $\checkmark$ & $\checkmark$ & $\checkmark$ & $\checkmark$ & $\checkmark$ & $\checkmark$ \\
\hline & Residential Townhouse (RT) & $\checkmark$ & $\checkmark$ & $\checkmark$ & & & & \\
\hline & Residential Detached (RD) & $\checkmark$ & & & & & & \\
\hline & Residential Semi-detached (RS) & $\checkmark$ & $\checkmark$ & & & & & \\
\hline & Residential Multiple (RM) & $\checkmark$ & $\checkmark$ & & $\begin{array}{lllllllll} & \end{array}$ & $\checkmark$ & $\checkmark$ & $\checkmark$ \\
\hline \multirow[b]{2}{*}{$\begin{array}{l}\text { Residental Apartment } \\
\text { Zone }\end{array}$} & Residential Apartment (RA) & & & & & & & $\checkmark$ \\
\hline & \begin{tabular}{|l|} 
Residential Apartment- \\
Commercial (RAC)
\end{tabular} & & & & & & & $\checkmark$ \\
\hline
\end{tabular}

Table 6: Permitted Housing Forms in Residential Zones (City of Toronto, 2013) 
detached houses (Table 6). The other residential zones are more permissive in permitted housing forms and densities but make up much less of the residential land area of the city. Although four of the five 'Neighbourhood' residential zones permit several housing forms, this does not mean that a diversity of housing options exist or is permitted. As shown by the previous example, an area zoned as RM which permits several housing forms, was exclusively occupied by one-storey single-detached houses. With the requirement that development respect the prevailing character and built form of a neighbourhood, Toronto is effectively limiting what can be built in its Neighbourhoods to what already exists: single-detached houses.

Although all population projections suggest that Toronto will continue to see strong population growth, the city's continued protection of neighbourhoods from increased density means that most of the growth will need to be accommodated in a small proportion of the city. This is officially recognized in the OP when it states:

The [Official] Plan's land use designations covering about 75 per cent of the City's geographic area will strengthen the existing character of our neighbourhoods, ravines, valleys and our open space system. These areas are not expected to accommodate much growth, but they will mature and evolve. Most of the new growth over the next 30 years will occur in the land use designations covering the remaining 25 per cent of the City's geographic area (Section 1-1).

Toronto's emphasis on stability within the residential neighbourhoods has resulted in them becoming rigid and ossified, unable to respond to changing conditions. These neighbourhoods are losing population due to the decline in household size and the inability of new housing to be created to compensate for this demographic change. As the population of Toronto increased by about 500,000 people over the last 20 years, these neighbourhoods saw a population decrease of about 200,000 people (Hertel and Scorgie, 2019: 79). Toronto must change its policies restricting increased density within residential neighbourhoods and permit new housing options and increased population within them.

The land available for residential development, permitted density, and housing form is shaped heavily by Toronto policy and not the market (Clayton and Petramala, 2019: 18). Current Toronto policy constrains development in the 'yellowbelt' by limiting appropriate housing forms to what already exists. Thus, these areas only permit the creation of single-detached housing and prohibit denser forms of ground-related housing. With land for residential needs constrained, most new development is directed towards mid- and high-rise development on the Avenues, downtown, and major centres (Clayton and Petramala, 2019: 18; Hertel and Scorgie, 2019: 80; Lorinc, 2019: 13). The Official Plan and the zoning bylaw therefore constrain the housing supply, 
prevent the diversification of housing options, and do not allow the market to respond to housing demand and consumer preferences.

\section{THE EXCLUSIONARY EFFECTS OF RESIDENTIAL ZONING}

Prior to World War 2, Canadian zoning was intended to prevent nuisances between incompatible land uses. However, after World War 2, zoning became seen as a tool planners could use to implement large scale plans by permitting or restricting change within an area (Cullingworth, 1987: 101). Support for this new vision of zoning was generated from appeals to the utility zoning would have in protecting property values: "the principle basis of political support for zoning was the desire to prohibit the intrusion of uses which could reduce neighboring property values ... planners appealed above all to the determination to maintain property values" (van Nus, 1979: 237). While zoning became a tool that created stability and maintained home values, it also contributed to several economic, social, and environmental costs (Pendall et al., 2006: 1).

Residential zoning, which limits what can be built in the name of stability and preservation of property values, is commonly referred to as exclusionary zoning: "The practice of banning certain types of land-uses intended to prevent racial and economic integration, most commonly resulting in banning all home types other than large, single-family, detached units - the most expensive form of housing" (Harrison and Kraemer, 2019: 7). This definition draws from the experience of exclusionary zoning in the United States which was heavily based in racial exclusion (Cullingworth, 1987: 99-100). While post-World War 2 zoning policies in Canada were not couched in terms of racial exclusion, they ultimately did result in having similar exclusionary impacts and therefore the critiques of exclusionary zoning are relevant in a Canadian context.

Exclusionary zoning is an intrusion into the housing market. The impacts of this type of zoning is a primary concern of this paper and the impacts of exclusionary zoning on the housing market are discussed in detail earlier in this paper. Exclusionary zoning effectively prohibits smaller, more affordable forms of ground related housing from being built by any housing provider - private, public, or non-profit - in existing neighbourhoods. This restricts large segments of the working- and middle-class segments of society from living in neighbourhoods with access to jobs, transit, and amenities (Einstein, 2019: 9; Harrison and Kraemer, 2019: 7). Neighbourhoods that have strict land use regulations tend to have higher housing values and as a result come to be segregated on the bases of class and race with expensive areas being occupied by upper-income households who are predominately white (Pendall et al., 2006: 8). 
Research indicates that land use regulations that restrict building housing that is affordable can have nationwide economic impacts. Hsieh and Moretti (2015) find that restrictions on housing supply in New York City, San Francisco, and San Jose have limited the number of workers who are able to access jobs in these cities; they estimate that the GDP of the United States would have been about 9.5\% higher in 2009 had land use regulations in these cities been more permissive in allowing housing to be built.

Development patterns that are supported by exclusionary zoning contribute to environmental degradation and climate change by limiting development densities and increasing the amount of land needed to provide housing. Low density residential areas require residents to rely heavily on private automobiles for their transportation needs as distances to jobs and amenities are often too far for walking to be a viable option and these areas are difficult to service efficiently using mass transit (Harrison and Kraemer, 2019; Pendall, 2019: 10). In addition to the environmental impacts caused by transportation patterns, low density residential neighbourhoods require more public investment in infrastructure, produce more hard surfaces which contribute to increase stormwater runoff, and consume large amounts of land that could be used for other uses (Pendall, 2019: 10). A recent opinion piece in the New York Times recognizes the relationship between low density housing and greenhouse gas emissions and concludes that any policy to combat climate change must include housing reform to allow higher density development near existing transit and jobs (Weiner and Kammen, 2019).

Exclusionary zoning also reifies political inequalities that prevail within cities (Einstein, 2019: 8; Fischel, 2004). Zoning, which was promoted as a tool to protect property values, is used by property owners to limit development and potential changes to their neighbourhood in order to protect their financial investment in the property. The need for public participation in the planning process has created forums that empower existing homeowners to advocate forcefully for their vision of a community's future (Einstein, 2019: 7). Public participation surrounding land use and development are dominated by a demographic that skews towards older, white, male homeowners who oppose construction of any new housing within their communities (Einstein, 2019: 2). Groups or individuals who would advocate for more housing are disadvantaged because they do not have the political influence, resources, or regulatory backing to effectively advocate their position (Einstein, 2009: 7). Furthermore, an important constituency is always absent from discussions about where housing should be located and what form it should take - the future inhabitants who will benefit from increased housing supply (Dougherty, 2020). The opposition towards housing development by homeowners is understandable because changing the neighbourhood through the introduction of new housing does introduce risk and potential 
nuisances associated with construction to homeowners, while offering them very little or no benefits (Einstein, 2009: 7).

Current planning practice establishes a 'normal' from which it is difficult to deviate (Levine, 2006: 76-77, 175). This normal was established in the past and the current built environment is the outcome of past housing demand and preferences. This built form, and the preference it represents, is codified into land use policy (Levine, 2006: 124). This is seen in the example from Toronto in which concerns about the impacts of multifamily housing on the integrity of families was encoded into a land use regulation which persists (even if the reasons for this regulation have changed). This approach benefits the status quo and current residents of a neighbourhood and makes it difficult to change the built environment when land economics, demographics, and consumer preferences demand alternative housing options be available in these locations. In these changing contexts where there is demand for alternative housing options, the onus is placed on those who want to deviate from the established 'normal' to prove scientifically that there would be a benefit from a land use policy change (Levine, 2006: 187).

In this sense the 'normal' becomes a political tool that can be used in disputes between interest groups over the ideal shape of urban development. Thus, zoning cannot be considered a purely economic variable in shaping urban densities (Frew et al., 1990: 157). Fischel (2004) expands on this idea and argues that the prevalence of restrictive single-family zoning is to provide homeowners, a powerful political bloc within cities, with insurance against declining home values. This reflects the tension between housing as a wealth generating investment that the city is obligated to protect and housing as a basic human need. However, there is no consensus on whether adding new housing in a neighbourhood depresses housing values. Mark and Goldberg (1986), in their examination of the impacts of zoning on housing values in Vancouver, find that non-single family land uses do not consistently have deleterious effects on the values of single family housing and that the values of single-family properties may be increased by proximity to other uses. The Centre for Housing Policy (n.d.) reviews the literature on the impacts of affordable housing development on property values and finds that in most cases property values are not depressed by the presence of affordable housing. Finally, Ihlanfeldt (2019) examines the impacts of rental properties on the value of single-family homes in Florida and finds that rentals, whether single-detached, mobile home, or apartment, have negative impacts on property values. However, he notes that rental units are critical for creating socially and racially inclusive neighbourhoods and therefore must be a housing option in most neighbourhoods (2019: 21) 
The planning 'normal' in Toronto is to protect stable neighbourhoods from change that would threaten neighbourhood character and property values. However, the literature on the impacts of housing development on existing property values cannot conclude with certainty that housing development will impact property values. Appeals to preservation of neighbourhood character are justifications for exclusion of newcomers into the community. Housing policy should not be beholden to planning inertia which seeks to continue doing what has been in the past. The position that requires scientific proof of the benefits of a policy change results in stagnation within neighbourhoods as they are unable to change to reflect the changing political, economic, and demographic contexts in which they exist. There is a large body of evidence that attest to the deleterious impacts of exclusionary zoning. Changing Toronto's Official Plan and zoning bylaw, which entrench exclusionary policies and prevent the creation of new housing in Toronto's neighbourhoods, must become a priority for the public good and for the creation of housing that is in demand within the city.

However, it must be noted, regulations cannot increase density beyond what the market will bear (Levine 2006: 109-110). Decisions on what and where to build are contingent upon land supply, land values, and demand for a particular form of housing. If these conditions are not met, development will not occur. However, development will occur where there is demand for increased housing supply to the extent that the land market will support the development. In these cases, the resulting density will be a balance of supply and demand and reflect peoples housing consumption preferences being met. This will result in the required diversity of housing options in a city required to meet the housing preferences of the population - in terms of housing typology, location, and price.

\section{FROM EXCLUSIONARY ZONING TO EQUITABLE ZONING}

With the recognition that exclusionary zoning contributes to social, economic, and environmental problems it is time to consider zoning reform with some planners calling for "Death to Single-Family Zoning" (Wegmann, 2020). Jenny Schuetz (2018) of the Brookings Institution succinctly explains that the goals of zoning reform are to simply build more housing, build less expensive housing, and build less expensive housing in desirable neighbourhoods and explains that there are three important questions to be answered when evaluating a zoning bylaw and recommending changes to it:

- $\quad$ Is the housing market producing enough additional housing to meet increased demand, as driven by population and job growth? 
- Within a city or metropolitan area, is new housing being built in the locations with highest demand (i.e., the neighborhoods where people most want to live)?

- Does the market provide a diverse range of housing choices that match household budgets, size, and other characteristics" (Schuetz, 2019)?

Harrison and Kraemer (2019: 8) suggest a move towards an equitable zoning: "laws requiring that diverse, economical home options such as duplexes, rowhouses, and garden apartments be allowed in all residential areas in order to promote racial and economic diversity." The calls to reform residential zoning are coalescing around the idea that zoning needs to allow missing middle housing. Missing middle housing (Figure 3) is a term coined by architect Daniel Parolek to describe "a range of multi-unit or clustered housing types [that are] compatible in scale with single-family homes" (Opticos Design Inc., n.d.) and that would provide a range of housing affordability and address mismatches between housing supply and housing demand (Opticos Design Inc., n.d.).

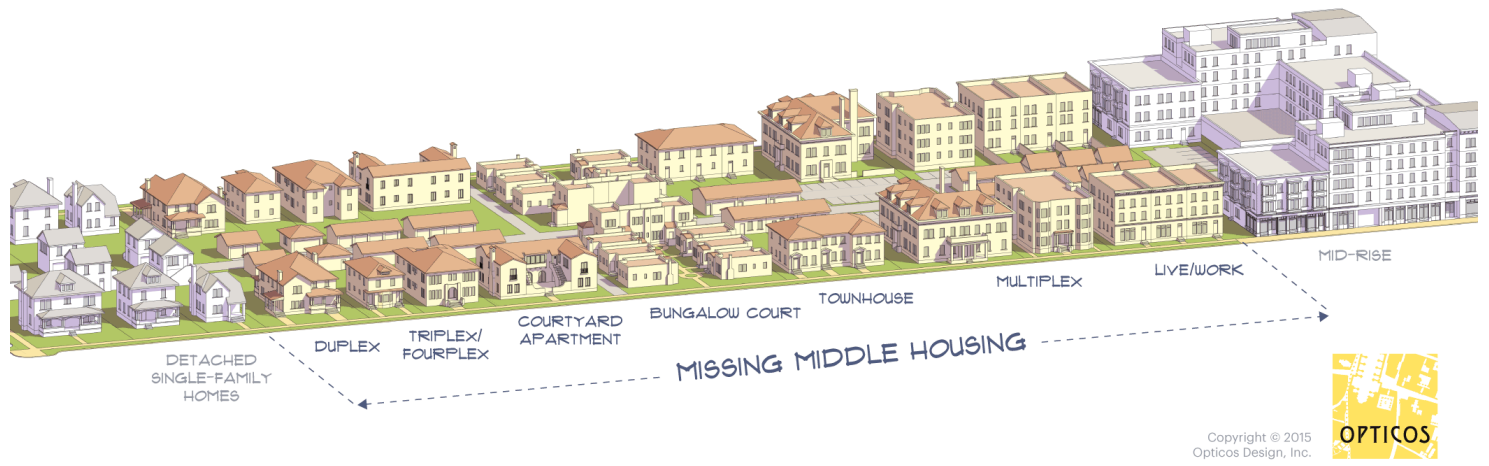

Figure 3: Missing middle housing forms (Opticos Design Inc, n.d.)

Reforming zoning bylaws to permit missing middle housing forms within zones that currently permit only single-detached houses addresses several of the problems associated with exclusionary zoning. First, single detached homes use the most land per household of any housing form; missing middle housing uses much less land. For example, a typical Washington, DC lot that has a single-family home could accommodate three townhouse units or a six-unit condominium building (Schuetz, 2020: 2). Missing middle housing forms use land more efficiently than single-detached housing and increases density within a neighbourhood. This allows the city to efficiently use existing infrastructure to provide amenities and services in these areas. An increase in density through building smaller units has important implications for actions for reducing emissions and addressing climate change. Placing housing in existing communities near transit and jobs will reduce the amount of time people spend traveling by private automobile as they walk, cycle, or use public transit. As well, smaller housing units will 
reduce household energy consumption as less energy is needed to operate these homes (Harrison and Kraemer, 2019: 43).

Second, missing middle housing can provide housing that is more affordable than singledetached houses. Placing more units on a single parcel of land reduces the land cost element associated with each unit (Baca et al., 2019, December 4). The Brookings Institution (Baca et al., 2019, December 4) examines the resale price of an old single detached house in Washington, DC vis-à-vis hypothetical townhouses or condominium units and finds that the condominium units would be about $40 \%$ less expensive than the single-detached house. However, the townhouses would cost about the same as the single-detached house. Thus, it is important to recognize that while zoning reform and the production of missing middle housing can produce housing that is affordable, it is not guaranteed based upon factors such as land values, construction costs, unit size, and number of units produced on a site. Incentives to produce lower cost housing options may be needed to ensure that housing that is accessible to households with a wide range of financial wherewithal may be needed. As well, depending on the strength of the housing market, rezoning to increase development permissions could result in higher land values causing missing middle housing to not be priced significantly lower than single-detached houses.

Finally, allowing missing middle housing into neighbourhoods dominated by singledetached houses helps to addresses the exclusionary impacts of exclusionary zoning. Increasing the supply of housing that is less expensive allows people from a wider spectrum of socioeconomic backgrounds to access these communities. This is significant because these older, developed neighbourhoods are often located near employment centres, transit, and amenities and services (Baca et al., 2019, December 4).

\section{CRITIQUeS OF Zoning RefORM to InCREASE HOUSING SUPPLY}

Despite the evidence that zoning reform is needed to permit increased housing supply in residential neighbourhoods there are dissenting arguments to this position. David Imbroscio explains that the 'Anti-Exclusionary Zoning Project' "embraces a set of pernicious normative values that give rise to sociopolitical outcomes far more detrimental to the cause of social justice than the actual adverse effects of EZ" (2019: 2). He suggests that efforts to reform zoning bylaws to allow missing middle housing is an acquiescence to neo-liberal ideology which seeks to deregulate the housing market to get housing built rather than fighting for affordable housing (2019: 10). However, this position equates reducing barriers to housing production with market deregulation (Goetz, 2019). The goal of zoning reform is not to remove zoning and provide the 
market carte blanche to reshape residential communities. Rather, zoning reform is the first step in creating the conditions in which new housing can be built in areas in which it is currently prohibited (Goetz, 2019). Any similarities between zoning reform and 'freeing' of the market is coincidental and not a reason to abandon zoning reform (Goetz, 2019: 13). Furthermore, depending on the market, further incentives and regulations may be needed to encourage desired housing development which represents a greater interference in the market (Goetz, 2019: 8). While Imbroscio misreads the intention of the 'anti-exclusionary zoning project' he makes an important point by recognizing that a market is "fundamentally unnatural and must be laboriously socially constructed and maintained" (2019: 12). Thus, a market which limits higher density forms of housing is created and maintained by policy decisions and political pressure. Changing regulations does not mean that the market is 'freed'. Changing regulations changes the context in which a market exists and fundamentally changes the market which can lead to desired outcomes: "Land use regulations can also promote beneficial development patterns that would not appear in their absence, shaping land markets to encourage high densities, mixed uses, and transit oriented developments that the market currently fails to provide in sufficient quantities" (Pendall et al., 2006: 2).

A consideration of the arguments of 'supply skeptics' is also important in a discussion of zoning reform with the goal of increasing housing supply. Supply skeptics propose that increasing the supply of market rate housing will not lead to housing becoming more affordable. This reasoning has contributed to opposition towards new housing construction and support of land use regulations that limit housing supply. This sentiment has also forged an unlikely common ground between those who oppose market housing because they believe that only affordable housing should be built and those who oppose market housing because they want to protect the character of their communities (Been et al., 2018: 1-2). The premise that new market housing will not contribute to housing affordability rests upon four arguments.

First, supply skeptics argue that land is a finite good and that any market rate housing produced takes away from the ability to produce affordable housing (Been et al., 2018: 2, 4). This argument assumes that all residential land is amenable to construction of affordable housing. However, some land is not supportive of affordable housing due to high land values. Housing costs are not solely a function of land scarcity or land values. The provision of affordable housing is also shaped by construction costs, financing costs, operating costs, and public policy which may require affordable units be provided (Been et al., 2018: 3-4). A final point to be made against this argument is that while land supply may be limited, land can be used intensely to provide more housing (Been et al., 2018: 4). This points to the importance of reforming land use regulations 
that limit how intensely land can be used for housing. By increasing the amount of housing that can be provided on a piece of land, more housing - both market rate and affordable - can be provided.

The second argument supply skeptics use to support their position is that new market rate housing will not filter down to lower income households and will not alleviate housing affordability pressures (Been et al., 2018: 2, 5). While filtering does take significant time due to the slow depreciation of housing prices, over a long-term time period this process does add significant amounts of housing at affordable price points (Been et al., 2018: 6). Furthermore, increased supply in one sub-market will have ramifications on other sub-markets. As housing is added to one sub-market people who can afford to buy or rent there will do so thereby reducing competition in other submarkets. This is seen when people who would prefer to own their home are priced out of the ownership market because of high housing prices. They either move out of the city or occupy housing in another, more affordable, submarket. This causes increased competition in the submarket that is more affordable, causing housing costs to rise (Been et al., 2018: 5).

Supply skeptics also worry about 'induced' demand. They posit that increasing housing supply contribute to more people moving to the city or new household formation. This increase in housing demand will lead to the cost of housing increasing and creating a cyclical need for more housing supply (Been et al., 2018: 2, 7). However, the increased demand for housing caused by supply increases is not likely to negate the benefits of new housing. Research shows that adding supply results to lower housing prices. If the increased supply was insufficient to meet the induced demand this research would not have found a relationship between housing supply and housing prices (Been et al., 2018: 8).

The final argument used by supply skeptics is that rents will increase and result in displacement in neighbourhoods that see increases in housing supply (Been et al., 2018: 2, 8). While there is a possibility that market rate housing will lead to gentrification as a neighbourhood gets new investment, it is also likely that construction nuisances will depress rents and housing prices. Research is inconclusive on the impacts on new market housing on existing home prices. Studies generally show that in areas that experience market rate housing developments, the values of existing properties increase. However, these studies cannot prove a causal link between the housing development and property values. Additionally, a California study finds that low-income neighbourhoods are less probable to experience displacement when there is market rate housing produced in them (Been et al., 2018: 9). 
Housing supply is shaped by the land use regulations that are in place within a municipality. When regulations limit this supply and make the housing market unable to effectively respond to increases in housing demand housing prices increase and the city becomes less affordable to its residents. Zoning is an important regulation that limits housing supply by restricting what can be built throughout the city. This is seen in Toronto where zoning (and the OP) protect stable neighbourhoods by preventing construction of missing middle housing forms; most housing being built in the city are apartment units (Table 4) despite a strong preference for ground related housing units. The need for expanding housing options throughout Toronto is being recognized by the city; in the summer of 2019 Toronto council adopted the item "Expanding Housing Options in Toronto- Tackling the Missing Middle and the 'Yellowbelt"' (City of Toronto, 2019) which called on City Planning to report, by the fourth quarter of 2019, on ways to increase housing options and needed changes to land use regulations. As of writing, this report has not been released.

While Toronto is beginning to consider the impacts that its land use regulations are having on housing supply within the city, other municipalities have reformed their zoning bylaws or are in the process of amending them to permit more housing forms within their single-family neighbourhoods. The next section of this paper will examine some of the policy changes happening in these jurisdictions to understand lessons that can be learned from them and applied to the Toronto context.

\section{CASe Study: California's Failed Attempts at Statewide Zoning REFORM}

California produced less than 80,000 new homes on average between 2008 and 2018, significantly lower than the projected annual need of 180,000 news homes (CDHCH, 2018: 3). The lack of supply to meet demand is expected to contribute to growing inequality within the state, segregation, and perpetuation of land extensive low-density development ( $\mathrm{CDHCH}, 2018: 3)$. The inability of the housing market to provide the housing supply that is in demand in California is contributing to increasing housing costs (Taylor, 2015: 3). California house prices and rents are the second highest in the United States (Taylor, 2015: 5). The median California household pays about $27 \%$ of their monthly income on housing while the median household in the United States pays only about $23 \%$ of their monthly income on housing costs (Taylor, 2015: 25). The median renter in California pays about 30\% of their monthly income on housing while the median homeowner pays about 20\% (Taylor, 2015: 26-27). Californians in the lowest income quartile spend, on average, 67\% of their monthly income on housing (Taylor, 2015: 26). 
To encourage increased housing production in California, State senator Scott Weiner introduced Senate Bill (SB) 827 in 2018. This bill would override local zoning regulation and provide a statewide 'transit-rich housing bonus' for development near major transit stops. Developments receiving this bonus would be exempt from local controls on:

- Maximum controls on residential density,

- Maximum controls on FAR that are lower than what is set in the bill,

- Minimum parking requirements,

- Maximum building heights that are less than specified in the bill, and

- Zoning or design controls that limit additions to existing structures if they comply with the FAR and height requirements set out by the legislation.

Development sites within a $1 / 4$ mile radius of a major transit stop would have a maximum height limit not less than 55 feet and a FAR not less than 3.25. Development sites within a $1 / 2$ mile radius would have a maximum height limit not less than 45 feet and a FAR not less than 2.5. Developments that receive this density bonus must abide by local inclusionary housing (IH) ordinances, both mandatory and voluntary. In instances where local IH ordinances do not exist, SB 827 required a development to provide a number of affordable units based upon the number of total units in the development and the level of affordability for the affordable units. Developers who would receive the 'transit-rich housing bonus' would be required to provide displaced tenants with state or local relocation benefits (including relocation costs and rent subsides), a right of first refusal for a comparable unit in the new development, and would need to ensure that the development did not result in a net loss of affordable units. Not all developments were eligible to receive this bonus. Ineligible properties are those that contain existing rental units subject to rent controls or another form of price increase control and properties in which, in the previous five years, tenants were evicted because the owner was removing the units from the rental market (i.e. Ellis evictions). SB 827 failed to pass the Senate Transportation and Housing Committee when it was defeated by a 4-6 vote on April 17, 2018.

Weiner reintroduced legislation to increase residential density in California in 2019 with SB 50. This bill was like SB 827 but granted more development rights than the earlier bill. SB 50 would require a local municipality to grant an 'equitable communities incentive' when a proponent seeks a neighbourhood multifamily residential development (Table 7). A neighbourhood multifamily residential development is one that constructs a structure of up to four residential units, either by converting an existing structure or by building on a vacant parcel. 


\begin{tabular}{|c|c|c|c|c|}
\hline Community Size & Location & Parking & Maximum Height & FAR \\
\hline \multirow{2}{*}{$\begin{array}{l}\text { Less than or equal to } \\
600,000 \text { residents }\end{array}$} & $\begin{array}{c}\text { Within a } 1 / 4 \text {-mile radius of a } \\
\text { rail transit station in a city } \\
\text { with more than } 100,000 \\
\text { residents }\end{array}$ & $\begin{array}{l}\text { Receive waiver from } \\
\text { any minimum parking } \\
\text { requirement }\end{array}$ & \multirow{2}{*}{$\begin{array}{l}\text { Receive waiver from } \\
\text { maximum height } \\
\text { requirements less than } \\
15 \text { feet above the } \\
\text { highest permitted } \\
\text { height for residential or } \\
\text { mixed uses }\end{array}$} & \multirow{2}{*}{$\begin{array}{c}\text { Receive waiver from } \\
\text { FAR less than } 0.6^{*} \\
\text { building height in } \\
\text { storeys }\end{array}$} \\
\hline & All other eligible locations & $\begin{array}{l}\text { Receive waiver from } \\
\text { minimum parking } \\
\text { requirements greater } \\
\text { than } 0.5 \text { stalls/unit }\end{array}$ & & \\
\hline \multirow{2}{*}{$\begin{array}{l}\text { Greater than } \\
600,000 \text { residents }\end{array}$} & $\begin{array}{c}\text { Between a } 1 / 4 \text { and a } 1 / 2-\text { mile } \\
\text { radius from a major transit } \\
\text { stop }\end{array}$ & \multirow{2}{*}{$\begin{array}{l}\text { Receive waiver from } \\
\text { minimum parking } \\
\text { requirements greater } \\
\text { than } 0.5 \text { stalls/unit }\end{array}$} & $\begin{array}{l}\text { Receive waiver from } \\
\text { maximum height } \\
\text { requirements less than } \\
45 \text { feet }\end{array}$ & $\begin{array}{l}\text { Receive waiver from } \\
\text { FAR less than } 2.5\end{array}$ \\
\hline & $\begin{array}{l}\text { Within a } 1 / 4 \text {-mile radius of a } \\
\text { major transit stop }\end{array}$ & & $\begin{array}{l}\text { Receive waiver from } \\
\text { maximum height } \\
\text { requirements less than } \\
55 \text { feet }\end{array}$ & $\begin{array}{l}\text { Receive waiver from } \\
\text { FAR less than } 3.25\end{array}$ \\
\hline
\end{tabular}

Table 7: SB 50 Equitable Communities Incentive

Residential developments eligible for the equitable communities incentive are those that are in a job-rich housing area or a transit-rich housing area, is on a site that permits residential use, existing on-site housing is not subject to rent controls or rent restrictions, the site is not susceptible to flooding or wildfire hazards or a heritage site, and the site has not had rental housing in the seven years prior to the application or had Ellis evictions in the 15 years prior to the eviction. Unlike SB 827, SB 50 did not include requirements to provided displaced tenants with relocation benefits, a right to return to the new development, or prevent a net loss of affordable housing units. Like SB 827, developments eligible for this incentive would be required to meet local IH requirements or the requirements established by SB 50. However, SB 50 granted more flexibility to developers over the required IH contribution by permitting cash-in-lieu payments, land dedications, provision of offsite affordable units, or acquisition or rehabilitation of existing affordable units to fulfil the IH requirement.

SB 50 provided exemptions for 'potentially sensitive' and 'sensitive' communities. An initial period would be provided in which defined potentially sensitive communities would be exempt from development receiving the equitable communities incentive. During this period sensitive communities would be identified, and these would continue to be exempt from the development incentives. The provisions of SB 50 could later be implemented in these communities if a local community plan is implemented that:

- protects residents from displacement, 
- promotes economic justice,

- was developed with a community organization that helps low-income residents,

- was created using community engagement, and

- is translated into the languages spoken by community members.

SB 50 allows local municipalities to implement a 'local flexibility plan' that would exempt them from being required to grant the equitable communities incentive. For a local flexibility plan to be accepted by the state it must further fair housing goals, achieve a standard of transportation efficiency equal to or greater than that created by the equitable communities incentive, and increase overall housing capacity for lower-, moderate-, and above moderate-income households. Unlike SB 827, SB 50 passed out committee, but it was ultimately defeated by a Senate vote.

Both SB 827 and SB 50 were highly contentious and attacked by both housing affordability advocates and neighbourhood protection groups. The Housing Rights Committee of San Francisco [HRCSF] (2019), a group concerned with tenant rights, explains that SB 50 would deregulate zoning, increase real estate speculation, incentivize luxury housing, and inflate rents and cause displacement. The bill was also criticized for not adequately providing protection to vulnerable communities (HRSCF, 2019) and for using vague and broad language that would result in many at risk communities being not designated as a sensitive community (Alliance for Community Transit, 2020; Cash et al., 2019; Terner Centre, 2020). The inclusionary housing requirements were also found to be inadequate as SB 50 takes away the ability of local governments to negotiate with developers to procure the affordable housing that is needed in the community (HRCSF, 2019). Furthermore, a letter to Scott Wiener (Alliance for Community Transit, 2020) by representatives of 28 groups concerned with affordable housing provision listed several problems with the proposed IH requirements:

- Despite granting significant density bonuses, SB 50 does not provide a guarantee that more affordable units will be provided where existing IH ordinances are in place.

- Units for extremely low-income households are optional.

- No affordability contribution is required for developments under 10 units.

As well, the IH requirements do not consider local market conditions and may result in some feasible developments becoming infeasible (Terner Center, 2020). The SB 50 provision to restrict demolition or redevelopment of properties that housed tenants in the last seven years was also criticized because, with no system in place to track rentals, it is nearly impossible to enforce these provisions (Alliance for Community Transit, 2019; HRCSF, 2019; Terner Center, 2020). The bill 
was also criticized for transferring power to make land use decisions from communities and local planning authorities to luxury housing developers which would "destroy thriving neighborhoods" (Livable California, n.d.a). Livable California, a group that advocates for the empowerment of local governments, claims that SB 50 is making "California cities face an existential battle to save their livability, affordability and environment from state Sen. Scott Wiener of San Francisco, and his dozen or so hardcore followers in the legislature, who embrace Wiener's failed theory that building dense luxury housing will 'trickle down' to the rest of us" (Livable California, n.d.b). Surprisingly, the Sierra Club (2018), which supports transit-oriented development as part of a fight against climate change, opposed SB 827 on the grounds that the state-level legislation takes away local decision-making powers.

Despite the criticism of SB 50, there were elements that were applauded. The expansion of the geographical scale of the bill to include job-rich areas and not only transit-rich areas as in SB 827 unlocked supply capacity over a greater area (Cash et al., 2019). However, the Terner Center (2020) recommends that SB 50 include residential development in commercial areas to be subject to the equitable communities incentive to unlock even more land for housing. Allowing for 'local flexibility plans' permits cities to decide how they would permit their zoning to accommodate increased housing capacity (Terner Center, 2020); however, as shown above, this did not allay the fears of some opponents of SB 50. SB 50 also provided developers of multi-family housing a streamlined planning process which would allow housing projects to be built faster and with less expense (Terner Center, 2020). Finally, analysis in the Bay Area suggests that market feasible capacity could be quadrupled in eligible areas, capacity for on-site inclusionary units could be quintupled, and that SB 50 could shift the market-capacity for housing towards higher resource areas and reduce impacts on low-resource communities (Cash et al., 2019).

\section{CASe Study: Portland's Residential Infill Project}

The City of Portland projects to add about 260,000 residents (123,000 households) between 2015 and 2035 (Bureau of Planning and Sustainability [BPS], 2015: 3). Along with a growing population, the demographics of Portland are also changing: the population is becoming older, more diverse, and living in smaller households (BPS, 2019a: 1). Portlanders are facing several housing challenges. First, there are limited options within residential neighbourhoods for the increasing number of smaller households. Current market conditions are continuing to promote the construction of larger houses within these neighbourhoods. While household sizes have been decreasing, the size of houses have been increasing (BPS, 2019a: 14). Second, Portland is facing rising housing costs. Between 2011 and 2015 the median purchase price of a home rose 
by $44 \%$ while median incomes rose only $9 \%$ (BPS, 2019a: 1 ). Third, there is a lack of diversity in the types of housing being built throughout Portland with apartments being the predominant typology; $76 \%$ of housing units build in 2016 were apartments (BPS, 2019a: 13).

To address these housing issues, Portland is currently conducting its Residential Infill Project which will produce the first comprehensive update to its single-family zones since 1991. In August 2019, City staff completed their recommended draft of proposed changes to Portland's single-dwelling zoning rules (BDS, 2019). The outcome of this project is to create the conditions in which more, smaller, and less expensive units can be created on each lot (BPS, 2019a: iii). Portland seeks to encourage 'missing middle' housing (duplexes, triplexes, and fourplexes) along with increasing the number of permitted accessory dwelling units through zoning changes. These housing forms are complementary to the existing built form that characterize Portland's neighbourhoods while increasing density and providing more options than apartments for housing that is affordable (BPS, 2019a: 5).

At the outset of the Residential Infill Program, in September 2015, a Stakeholder Advisory Committee was appointed to advise the Bureau of Planning of Sustainability through the project. Committee members were nominated to ensure a range of interests were represented. The committee included representatives from government departments, community interests, developers, home builders, anti-displacement activists, Metropolitan Portland, immigrant activists, refugee activists, and senior citizen representatives (BPS, 2019a: 6). The Bureau of Planning and Sustainability also conducted an extensive and inclusive public outreach program to generate initial recommendations for the Residential Infill Project (BPS, 2019a: 6). The public was offered a nearly two-week period to comment on the Residential Infill Project Discussion Draft. During this period, a kick-off meeting was held, six drop-in events were held throughout the city, and city staff presented the proposal at community meetings and in conversations with concerned groups and individuals (BPS, 2019a: 9). The feedback generated through this process informed the Proposed Draft of the Residential Infill Project. The public was again invited to provide feedback on the Project and this feedback was considered in the preparation of a revised proposed draft and the final recommended draft (BPS, 2019a: 9-10). The Residential Infill Project began in 2015 and, as of writing, is still engaging with the public. The early efforts at bringing in important parties into the process and engaging with the public to create the framework for zoning reform appears to have been effective in generating support for the project. Over two days of public hearings in January, 2020, more than 140 community members testified, most of them in support of zoning reform to allow more housing in single-dwelling zones (Portland, 2020, January 21) 
Portland's 2035 Comprehensive Plan requires new plans to consider how they may contribute to displacement or result in higher housing costs in vulnerable communities. As part of the Residential Infill Program two development scenarios were created as part of a displacement risk analysis - one using current zoning and one using the proposed zoning from the Residential Infill Project. Analysis of these scenarios suggests that the proposals emerging out of the Residential Infill Project would result in more housing being built on fewer lots. This would mean that fewer lots are being redeveloped and therefore fewer people would be displaced. Under the proposed zoning regime, the displacement risk analysis concluded that there would be a $28 \%$ reduction in indirect displacement for low-income renters living in single-detached homes. In neighbourhoods classified as Displacement Risk Areas, there is a 21\% reduction of indirect displacement risk for low-income renters in single-detached houses (BPS, 2019b: 4). Furthermore, this analysis suggests that the Residential Infill Program would increase housing supply, increase housing options, and increase the availability of less-expensive housing (BPS, 2019a: 19). To further examine the potential displacement caused by zoning reform and to develop and implement anti-displacement policies, Portland began an Anti-Displacement Action Plan in August 2019; city staff are expected to report to City Council in spring 2020 (City of Portland, n.d.).

Portland's Bureau of Planning and Sustainability (2019) Residential Infill Program draft recommendations report proposes 12 amendments to Portland's zoning code to modify three single-dwelling zones: R7, R5, and R2.5. This paper will discuss the first seven proposed amendments, those concerned with 'housing options and scale' rather than the last amendments that seek to regulate 'building design'. The 'housing options and scale' amendments are directly related to the goals of increasing housing supply, housing options, and reducing housing costs.

The first proposal is to allow for more housing types in R7, R5, and R2.5 zoned properties (BPS, 2019a: 12-15). Current zoning regulations permit single detached houses, attached houses where each house is on its own lot, duplexes on corner lots and transitional lots, and accessory dwelling units (Bureau of Planning, 1991). This proposal would permit single detached houses, duplexes, triplexes, and fourplexes in these zones. A single detached house would be permitted to have two accessory dwelling units while a duplex would be permitted one accessory dwelling unit. This increase in unit types would be restricted in lots that only front onto unpaved streets, lots that have a landslide hazard, flooding potential, or that are identified as being environmentally important, and lots that do not meet a minimum lot size. These restrictions are to ensure adequate access, public safety, and that units created are not excessively small and have suitable area for yards and parking. 
The second proposed amendment to Portland's zoning code is to limit the size of buildings (BPS, 2019a: 16-19). This will be achieved through establishing a floor to area ratio (FAR) that results in smaller buildings. Current zoning does not utilize FAR but instead provides maximum building coverage and maximum height. Moving to FAR to limit building size would allow Portland the flexibility to provide development standards that do not restrict redevelopment, especially on smaller lots; this would also provide the flexibility to scale the permitted FAR on a site as the number of dwelling units increase (Table 8). A further bonus to FAR would be provided when at least one of the units on a site is rented at $80 \%$ of the median family income or if units are added to an existing house without substantially changing the façade of the structure. City staff is considering amending this bonus with an additional increase in FAR for projects that provide more affordable units or units at a greater level of affordability (Portland, n.d.)

\begin{tabular}{|c|c|c|c|c|c|}
\hline \multirow[b]{2}{*}{ Zone } & \multirow[b]{2}{*}{$\begin{array}{l}\text { Number } \\
\text { of Units }\end{array}$} & \multicolumn{2}{|c|}{ Current Zoning } & \multicolumn{2}{|c|}{ Proposed Zoning } \\
\hline & & $\begin{array}{c}\text { Estimated } \\
\text { FAR* }^{*}\end{array}$ & $\begin{array}{l}\text { Maximum } \\
\text { Dwelling } \\
\text { Size }\left(\mathrm{ft}^{2}\right)\end{array}$ & $\begin{array}{c}\text { Proposed } \\
\text { FAR }\end{array}$ & $\begin{array}{l}\text { Maximum } \\
\text { Dwelling Size } \\
\left(\mathrm{ft}^{2}\right)^{* * *}\end{array}$ \\
\hline \multirow{2}{*}{ R7 } & 1 & 1.1 & 7700 & 0.4 & 2800 \\
\hline & $3-4$ & \multicolumn{2}{|c|}{$N A^{* *}$} & 0.7 & 1633 \\
\hline \multirow{2}{*}{ R5 } & 1 & 1.35 & 6750 & 0.5 & 2500 \\
\hline & $3-4$ & \multicolumn{2}{|c|}{$N A^{* *}$} & 0.8 & 1333 \\
\hline \multirow{2}{*}{ R2.5 } & 1 & 1.75 & 4375 & 0.7 & 1750 \\
\hline & $3-4$ & \multicolumn{2}{|c|}{$N A^{* *}$} & 1 & 833 \\
\hline \multicolumn{6}{|c|}{$\begin{array}{l}\text { *Estimated FAR based on maximum building size under current zoning } \\
{ }^{* *} \text { Current zoning does not permit this many units } \\
\text { ***For multi-residential dwellings assume } 3 \text { units/lot }\end{array}$} \\
\hline
\end{tabular}

The third proposed amendment is to ensure that for lots with three or four units, one unit on the site must be 'visitable'. (BPS, 2019a: 20) by having a no-step entry, wider doorways, and living space and bathroom on the ground floor. These requirements are to ensure housing is provided for people with mobility issues, to ensure that elderly people have the option to stay in their neighbourhood as they change housing, and to offer convenience.

The fourth proposal is to require at least two dwelling units when new development occurs on lots that are twice the size required for the zone. This will ensure that when a house on an oversized lot is demolished it will be replaced with smaller units rather than one large unit (BPS, 2019a: 21). 
The fifth proposed amendment would see half of Portland's historically narrow lots in the R5 zone be rezoned to R2.5. The other half of these lots would be permitted to be developed with pairs of attached houses. This proposal seeks two outcomes. First, by rezoning the narrow sites to R2.5, development on these sites can take advantage of the greater proposed FAR and construct larger buildings than would be possible under the $\mathrm{R}_{5}$ zone. Secondly, the attached houses built would be amenable to fee-simple ownership, rather than condominium ownership or rental tenure (BPS, 2019a: 23-25).

The sixth proposed amendment is to use the process for adjusting property lines for creating flag lots in R2.5 zones and narrow lots in the R5 zone rather than the slower and more expensive land division process (BPS, 2019a: 26). This proposal would encourage the creation of additional lots that would be amenable to smaller, less expensive housing opportunities. Finally, the seventh proposed amendment relating to 'housing options and scale' is to conduct planned development reviews for developments that may not conform to base zone development typologies but which may contribute to the desired outcomes of providing affordable housing options within existing neighbourhoods (BPS, 2019a: 27-28).

Proposed amendment 11 of the Residential Infill Project is also important to Portland's efforts to reduce housing size and increase residential densities. This would impact parking requirements for houses, duplexes, triplexes, and fourplexes across the city by removing the minimum parking requirements from the R2.5 zone (BPS, 2019a: 35). Addressing parking requirements is important because parking is a 'poison pill' for affordable housing development (Schuetz, 2018) and contribute to higher housing costs or fewer residential units being provided (Jaffe, 2015).

The zoning amendments proposed by the Residential Infill Program is expected to result in housing capacity being added incrementally. Portland recognizes that as houses age and are rehabilitated, remodeled, or replaced opportunities arise to introduce missing middle housing forms into the existing single-dwelling neighbourhoods. These housing forms are responsive to changing demographic needs as people need smaller homes as they age or live in smaller households. These housing forms are also recognized to be responsive to different economic needs and offer homes at more diverse price points. The proposals in the Residential Infill Project are expected to "reduce the cost of housing, limit the size of new houses, mitigate and lessen displacement citywide, and prioritize a wide range of housing types for people of all ages, abilities and incomes" (BPS, 2019a: iv). 
It is important to note that the proposals in the Residential Infill Project are not adopted policy. These are still recommendations that need to be approved by Council. Once approved, Portland's zoning code must be amended to put them into force. However, even if the Residential Infill Program is not approved, Portland must amend its zoning code to conform to state law. Oregon House Bill 2001, which was passed by the House and Senate and signed into law in 2019, requires each municipality with a population greater than 25,000 to allow for all missing middle housing types in residential zones that allow for single detached units, and to allow a duplex on each parcel zoned to allow single detached units. In this legislation, middle housing refers to duplexes, triplexes, quadplexes, cottage clusters, and townhouses. Portland will be discussing minor amendments to its Residential Infill Project in spring 2020 to bring it into full conformity with HB 2001 (Portland, 2020, February 14).

\section{CASE StUdy: MinNeAPOLIS 2040}

Thirty-seven (37) percent of Minneapolis households are cost burdened (spending more than 30\% of household income on housing). Affordability pressures are not distributed evenly across racial lines in Minneapolis. Over 50\% of black and American Indian households, over 45\% of Hispanic households, and about 33\% of white households are cost burdened (Community Planning and Economic Development [CPED], 2019, October 25: 15). This is partially attributable to an increase in population since 2000 which has increased housing demand without an adequate increase in supply. Also, wages have not increased as fast as rents resulting in 15,000 units becoming unaffordable for those earning 50\% of the area median income. This is especially prevalent amongst black households who have seen their incomes drop by about $40 \%$ since 2000 (CPED, 2019, October 25: 83). The racial housing and economic disparities are linked to historical discriminatory housing policies and practices, chief among them are zoning policies. Zoning was used to create a "homogenous and harmonious neighborhood" (CPED, 2019, October 25: 84) and worked with racist federal policy to determine where people could live and in what type of housing. Racialized people were directed to high-density areas that were disinvested in and which shaped the opportunities available to people. The legacy of these racist policies persists in Minneapolis and continue to be seen in the zoning map which has remained largely unchanged since it was created (CPED, 2019, October 25: 84).

Minneapolis is cognizant that the benefits and harms of growth have accumulated along racial and class lines. To redress the inequitable distribution of the benefits of growth, the Minneapolis 2040 Plan creates the regulatory environment to encourage the development of multi-family housing of varying sizes and affordability levels throughout the city (CPED, 2019, 
October 25: 14-17). The city has established the goal of ensuring that all Minneapolis residents will have access to and be able to afford quality housing throughout the city by 2040 (CPED, 2019, October 25: 19). This is a very lofty, broad, and complicated goal as evidenced by the Plan having 22 policies related to the achievement of this goal, including policies on affordable housing, displacement, innovative housing types, mixed income housing, fair housing, tenant protections, and community benefits through housing programs (CPED, 2019, October 25: 22).

The first policy established in the Minneapolis 2040 Plan is to increase access to housing by increasing the supply of housing and increasing the diversity and locations of housing (CPED, 2019, October 25: 105-107). The City has identified four strategies to increase housing supply and housing choice. The first is to allow multifamily housing along transit routes and to allow increased density near high-frequency routes and METRO stations. Second, in neighbourhoods that contain a mix of housing typologies, new housing within this range will be permitted. Third, high-density housing will be allowed in and near the downtown. Finally, in neighbourhoods that are primarily reserved for single detached housing, Minneapolis' zoning ordinance will be amended to permit up to three dwelling units per lot. Minneapolis recognizes that regulatory changes to allow increased housing supply is a prerequisite to achieve increased production of market rate housing and the production and preservation of affordable housing. It is expected that implementation of this policy will encourage an increased supply of housing which will result in lower housing costs (CPED, 2019, October 25: 105-106).

Like Portland, Minneapolis will address parking requirements. The Minneapolis 2040 Plan eliminates off-street parking minimums throughout the city. This does not prohibit the provision of off-street parking but allows for the supply of parking to be determined by market demand rather than by regulation (CPED, 2019, October 25: 119).

Minneapolis City Council adopted a resolution to approve the Minneapolis 2040 Comprehensive Plan on October 25, 2019. Policy changes within this document took effect on January 1, 2020 (Minneapolis 2019a). Zoning and subdivision ordinances are to be dealt with in the short-term (0-5 years) when Minneapolis will conduct a rezoning study to bring existing zoning into consistency with adopted land use (CPED, 2019, October 25: 260). However, on November 8, 2019, Minneapolis City Council adopted Ordinance 2019-048. This ordinance amends the Zoning Code to permit up to three-unit residential units on lots in lower-density zoning districts and amends development standards (CPED, n.d.). This ordinance was signed by the mayor on November 13, 2019 and came into effect on January 1, 2020 (Minneapolis, 2019b). 
The City of Minneapolis recognized that minorities and low-income people have been excluded from civic governance. One of the reasons for this is the disenfranchisement of these communities and the perpetuation of barriers to their meaningful contribution in engagement activities. The engagement process for the Minneapolis 2040 Plan process was "designed and conducted in a way to create equitable and innovative ways to engage populations that have been historically underrepresented in civic life" (CPED, 2019: 285). The engagement process was guided by the goals of meaningful and relevant dialogue, inclusive representation, access to information and activities, contributions have impact, empowering experience, and effectively used resources (CPED, 2019: 287-288). City staff identified 20 key audiences whose engagement in the process would best contribute to meeting the goals of the engagement process. These audiences were engaged using traditional and novel interactive techniques that were intended to inform and generate feedback. These techniques included: community workshops, community dialogues, street festivals, artist-designed engagement, online engagement, meeting-in-a-box, and tweet with a planner (CPED, 2019: 289-290). Throughout the engagement process, feedback was documented and was used to inform successive outreach activities. Summaries of engagement activities and transcripts of received feedback was published online to be made available to the public (CPED, 2019: 291-292).

Policy 37 of the Minneapolis 2040 Plan recognizes that the market will not be able to provide housing that is affordable to all residents and the city may need to intervene to ensure that market rate and affordable housing is available at all levels of affordability (CPED, 2019:168). To spur the development of missing middle housing Minneapolis Council approved the Missing Middle Housing Pilot Program and issued a request for proposals on June 15, 2019 (Minneapolis, 2019c). This program is tied to the Minneapolis 2040 Plan's aims of increasing the supply and diversity of housing and is intended to develop between three to 20 rental or ownership units on vacant land. The city will provide funding of up to $\$ 70,000$ per affordable unit, proposals that display a "compelling basis for deeper subsidy" may receive \$95,000 per affordable unit (Minneapolis, 2019, May 1). To support this program, $\$ 500,000$ was allocated towards this program in the City's 2019 budget (Minneapolis, 2019d). City staff recommended three projects that would produce 28 long-term affordable units and 50 total units in February 2020. Funding recommendations exceeded the program budget with the deficit being made up from funds from other programs (Minneapolis, 2020a) These recommendations were approved by City Council on February 28, 2020 and signed by the Mayor on March 2, 2020 (Minneapolis, 2020b). 


\section{CASe Study: Seattle's Mandatory Housing Affordability and NeIGHBOURHOOdS FOR ALL}

Seattle has the need for more affordable and market rate housing. Seattle is one of the fastest growing cities in the United States and saw its population grow by $15.7 \%$ between 2010 and 2016. Seattle is experiencing growth in the housing market in response to increased demand for housing with 15,000 units being added since 2015 and more than 22,000 housing units that are uncompleted. However, there has been significant increases in housing costs. For example, the average rent for a one-bedroom apartment increased by 35\% between 2010 and 2016. About 45,00o households ( 1 in 7 ) continue to pay more than half their income on housing. Furthermore, city analysis finds that Seattle needs 27,500 to 36,500 units rented at or below 80 percent of area median income to meet population growth needs. This does not include existing affordable housing needs, so the number of units needed is higher than this amount (Seattle 2018: 6)

In the report, Housing Seattle: A Roadmap to an Affordable and Livable City (Seattle, 2015), the city establishes a goal of producing 50,000 new housing units over 10 years, with 20,000 of these being designated affordable units. In this report, the city identifies a variety of methods that are needed to achieve this goal including mandatory inclusionary housing, expansion of lands on which multi-family housing is permitted, tax exemptions and incentives to promote multi-family housing, parking reform, streamlining the permitting process, and providing public land for multi-family housing.

The Mandatory Housing Affordability (MHA) program has been implemented as one prong in Seattle's attempts to increase both market rate and affordable housing. While Minneapolis and Portland turned to changing zoning for large swaths of single-family zoned areas, Seattle turned to zoning reform and inclusionary housing in limited areas to encourage new housing. Most development and upzoning will occur on blocks where commercial and multifamily zoning is already predominant with only 6 percent of areas zoned for single family housing being impacted (Beekman, 2019). This aligns the MHA program with the Seattle 2035 Comprehensive Plan which aims to direct most growth towards areas defined as 'Urban Villages' (Seattle, 2018: 4).

Throughout 2017, Seattle created its first six MHA areas. On March 18, 2019, 27 additional MHA areas were established in designated Urban Villages. The creation of these MHA areas is supported by rezoning within these areas that allow larger buildings to be constructed in exchanged for mandatory provision of affordable dwelling units or a cash payment into an 
affordable housing fund. Seattle expects that 62,387 units will be created in the $27 \mathrm{MHA}$ areas established in 2019 over 20 years, 5,633 of these units are expected to be rent and income restricted. Without the MHA program it is estimated that only 42,461 units would be created and only 205 of these would be rent and income restricted (Seattle, 2018: 4).

The required developer contribution under the MHA program is determined by two variables. The first is the strength of the market that a development is located in. Three tiers of housing market strength have been identified in Seattle: high, medium, and low (Community Attributes Inc., 2016). Developments in high strength markets are required to make a greater contribution than those in low strength markets. The second variable is the degree to which a site in an MHA area has had its development capacity increased by upzoning. Three zoning suffixes were created to identify this. The 'M' suffix is applied to sites ( $78 \%$ of sites within MHA areas) where the zone remains the same or changes to a zone in the same category. The 'M1' suffix is applied to sites (20\% of sites within MHA areas) that are rezoned to a zone that is one category higher, and the 'M2' suffix is applied to sites (2\% of sites within MHA areas) that are rezoned to a zone that is two or more categories higher (Seattle, 2018: 20). In determining the extent to which an area could be rezoned to increase development capacity, Seattle was concerned about increased development pressures resulting in displacement of vulnerable, low-income residents. Sites that receive the M1 and M2 zoning suffixes are those that are identified as having the capacity to accommodate higher density development without resulting in displacement of low-income residents (Seattle, 2018: 20). Zoning categories are displayed in Table 9.

\begin{tabular}{|c|c|c|c|c|}
\hline $\begin{array}{c}\text { Zoning } \\
\text { Category } 1\end{array}$ & \begin{tabular}{|c} 
Zoning Category \\
$\mathbf{2}$
\end{tabular} & $\begin{array}{c}\text { Zoning } \\
\text { Category } 3\end{array}$ & $\begin{array}{c}\text { Zoning } \\
\text { Category } 4\end{array}$ & $\begin{array}{c}\text { Zoning Category } \\
\mathbf{5}\end{array}$ \\
\hline $\begin{array}{l}\text { Single-Family } \\
\text { Residential } \\
\text { Small Lot }\end{array}$ & $\begin{array}{c}\text { Lowrise } 1 \\
\text { Lowrise } 2 \\
\text { Neighbourhood } \\
\text { Commercial } 30\end{array}$ & $\begin{array}{c}\text { Lowrise } 3 \\
\text { Neighbourhood } \\
\text { Commercial } 40 \\
\text { Neighbourhood } \\
\text { Commercial } 50\end{array}$ & $\begin{array}{l}\text { Zones with } \\
\text { height limits } \\
\text { between } 55 \\
\text { and } 95 \text { feet }\end{array}$ & $\begin{array}{l}\text { Zones with } \\
\text { height limits } \\
\text { over } 95 \text { feet }\end{array}$ \\
\hline
\end{tabular}

Table 9: Zones within Seattle Zoning Categories (Seattle, 2019: 2)

Required affordable units are calculated as a percentage of total residential units created or, in commercial development, as a percentage of gross floor area. Payments in lieu of affordable units are calculated by multiplying the payment rate by gross floor area of the residential or commercial development. The payment rates are indexed to the Consumer Price Index to ensure they increase over time (Seattle, 2018: 10). 
Zoning changes that occur through the MHA program contain two aspects. The first being the upzoning of a parcel to accommodate more intense development and the second being changes to development standards within a zone to further permit increased density within the zone.

Most sites within MHA areas initially zoned as Single-Family 5000 or Single-Family 7200 were rezoned as Residential Small Lots (RSL). Single-Family zones allow one dwelling unit on each lot. Rezoning to RSL changes the permitted density of these lots to one unit per 2,000 square feet of lot area and reduces front and rear setbacks. This will allow one or more dwelling unit to be placed on each lot. This rezoning also expanded the range of permitted housing types by permitting attached or stacked dwelling units (Seattle, 2018: 36).

Most sites within MHA areas that were zoned as Lowrise 1 (LR1), Lowrise 2 (LR2), or Lowrise 3 (LR3) retained their original zoning. However, the amount of land zoned for LR1 was increased by about $100 \%$, the amount of land zoned for LR2 increased by $70 \%$, and the total area of the LR3 zone increased by about $10 \%$. These increases in the areas of land in these three zones is significant as they permit housing typologies commonly labelled as the 'missing middle'. All three of these zones were modified to allow greater FAR and reduced parking requirements. Development potentials of these sites were increased through further revised development standards. LR1 zones saw increased density permissions for townhouses and rowhouses and LR2 and LR3 zones had height limits increased (Seattle, 2018: 42-53).

Properties in Commercial or Neighbourhood Commercial zones generally were rezoned to allow an increase in FAR and a 10-foot (1 storey) height increase (Seattle, 2018: 54-68). The Midrise Multifamily (MR) zone was modified to increase the permitted FAR by $40 \%$ and the development capacity within the Highrise Multifamily Zone was increased by permitting a FAR up to 15 and increasing permitted height from 300 to 440 feet (Seattle, 2018: 70-76).

On August 1, 2019 the Seattle Planning Commission (2018) presented a report to City Council titled "Neighbourhoods for All: Expanding Housing Opportunity in Seattle's SingleFamily Zones". This report identifies several ongoing problems in Seattle's housing market including rising housing costs, declining population in their single-family zones, the predominance of apartment units being produced, and the unequal distribution of the benefits of growth. To address these issues in the housing market, the Commission made a series of policy recommendations for Council and the Mayor to further explore. These recommendations include changing the single-family zone to neighborhood residential that would permit a range of housing options to be built. This recommendation suggests that there continues to be a demand for 
increased upzoning throughout Seattle, not just in MHA areas. The Seattle Planning Commission (2020) released a white paper, Evolving Seattle's Growth Strategy, as a follow-up to the Neighbourhoods for All report. This paper evaluates Seattle's current growth strategy and presents broad strategies to address historical racial inequities, reduced housing options, and public transit for the City to consider as it begins the process to update its Comprehensive Plan in 2023 (Seattle Planning Commission, 2020). This white paper explains how Seattle's Urban Village model has resulted in about 80\% of Seattle's new housing being built in the Urban Villages while single-family zoned areas received only $6 \%$ of housing growth despite constituting $75 \%$ of residential land (Seattle Planning Commission, 2020: 9). The impacts of these growth patterns disproportionately impacted low-income households and communities of colour who are priced out of high amenity neighbourhoods and is inconsistent with Seattle's commitment to reverse racial inequities in city policies (Seattle Planning Commission, 2020: 3). As well, the Urban Villages strategy does not promote liveable and sustainable communities across most of the city and limits housing options primarily to single-detached houses or apartment units. This makes it difficult for people of different household sizes, incomes, and life-stage to find housing that best suits their needs (Seattle Planning Commission, 2020: 10). 'Evolving Seattle's Growth Strategy' (Seattle Planning Commission, 2020: 11) recognizes that the process to update Seattle's Comprehensive Plan offers the opportunity to engage with communities to develop the best ways for adding missing middle housing into exclusive single-family areas. The Seattle Planning Commission (2020: 11-12) also recognizes the need to incorporate anti-displacement strategies and renter protections into changes to the growth strategy and will make future recommendations considering the work of the Equitable Development Monitoring Program.

\section{CASe Study: Edmonton's Evolving Infill Project}

The City of Edmonton's Municipal Development Plan (MDP) acknowledges that growth patterns in Edmonton have promoted scattered neighbourhoods which have created challenges for the city to meet its financial, social, environmental, and cultural sustainability goals. This growth pattern is contributing to increased costs of building, maintaining, and replacing infrastructure, encourages automobile use, increases health risks, and contributes to environmental degradation (Edmonton, 2010: 11-12). The city expects to grow to between 1,000,000 and 1,200,000 people by 2040 and recognizes the importance of ensuring the development potential for single- and multi-family housing is available (Edmonton, 2010: 20). Section 3 of the MCP outlines the city's strategy for managing growth. As a preamble to this section, it is explained that while Edmonton's mature neighbourhoods received $18 \%$ of new 
housing growth in 2007 the population of these neighbourhoods is declining (2010: 17). Over the last 40 years the population of Edmonton's mature neighbourhoods have declined by about 73,00o people (Edmonton, n.d.a). Edmonton established a goal of supporting a shift from suburban development and increasing density by encouraging $25 \%$ of new housing growth to be in core or mature areas (2010: 19). The creation of new, diverse housing options in mature neighbourhoods is presented as being supportive of these communities rather than a threat to their character and stability: "Enduring communities with character and vitality rely on a complete range of components in addition to a varied housing stock and transportation options" (Edmonton, 2010: 30) and "A variety of housing choices contributes to the long term stability of a neighbourhood and creates a varied built form which enlivens the physical and social character of the neighbourhood" (Edmonton, 2010: 31).

The City of Edmonton (2019b: 5) launched its Evolving Infill Project in 2013 and released its first Infill Road Map the next year (Edmonton, 2014). This road map presents the framework for increasing housing growth in Edmonton's established neighbourhoods and was intended to provide a two-year work plan to encourage and advance infill development in the city. Infill development is presented as an opportunity to create diverse housing options for a growing and diversifying population and a means to ensure that people could find the right home in the right area. This plan established 23 action items to help the City communicate effectively, remove barriers to infill, and support the development of infill (Edmonton, 2014: 3-4). An updated Infill Roadmap with a focus on "supporting infill as it relates to 'missing middle' housing forms" (Edmonton, 2018a: 28) was released in 2018, with missing middle housing defined as triplexes, fourplexes, row-houses, stacked row-houses, and low-rise (up to four storeys) and mid-rise (up to six storeys) apartments (Edmonton, 2018a: 29). The question, "how can we welcome more people and new homes into our older neighbourhoods", was created to capture the unifying goal of this project (Edmonton, 2018a: 28). The geographical focus on 'older neighbourhoods' expands the scope of this roadmap to include Edmonton's core, mature, and established neighbourhoods. This plan identifies 25 actions, organized into five broad categories, for the city to undertake to ensure more people and homes are welcomed into older neighbourhoods (Table 10). 


\begin{tabular}{|c|c|c|c|c|c|}
\hline Knowledge & $\begin{array}{l}\text { 1. Prioritize infill at } \\
\text { key nodes and } \\
\text { corridors }\end{array}$ & $\begin{array}{l}\text { 2. Review } \\
\text { infrastructure } \\
\text { capacity }\end{array}$ & $\begin{array}{l}\text { 3. Investigate } \\
\text { opportunities for } \\
\text { tiny homes }\end{array}$ & $\begin{array}{l}\text { 4. Re-examine } \\
\text { collective housing } \\
\text { regulations }\end{array}$ & \\
\hline Collaboration & $\begin{array}{l}\text { 5. Partner to pilot } \\
\text { innovative housing }\end{array}$ & $\begin{array}{l}\text { 6. Improve } \\
\text { housing } \\
\text { affordability }\end{array}$ & $\begin{array}{l}\text { 7. Address land } \\
\text { assembly and } \\
\text { mixed use }\end{array}$ & $\begin{array}{l}\text { 8. Pilot alley } \\
\text { enhancements }\end{array}$ & \\
\hline Advocacy & $\begin{array}{l}\text { 9. Better inform } \\
\text { residents }\end{array}$ & $\begin{array}{l}\text { 10. Incentivize } \\
\text { accessible laneway } \\
\text { homes }\end{array}$ & $\begin{array}{l}\text { 11. Create optimal } \\
\text { infill map }\end{array}$ & $\begin{array}{l}\text { 12. Reduce barriers } \\
\text { to use of Low } \\
\text { Impact } \\
\text { Development }\end{array}$ & \\
\hline Process & $\begin{array}{l}\text { 13. Monitor and } \\
\text { address } \\
\text { construction issues }\end{array}$ & $\begin{array}{l}\text { 14. Improve } \\
\text { permitting process } \\
\text { timelines and } \\
\text { consistency }\end{array}$ & $\begin{array}{l}\text { 15. Review, update } \\
\text { or retire plans and } \\
\text { policies }\end{array}$ & $\begin{array}{l}\text { 16. Review, update } \\
\text { or retire plans and } \\
\text { policies }\end{array}$ & $\begin{array}{l}\text { 17. Improve lot } \\
\text { grading }\end{array}$ \\
\hline \multirow{2}{*}{ Rules } & $\begin{array}{l}\text { 18. Improve } \\
\text { medium scale } \\
\text { zones }\end{array}$ & $\begin{array}{l}\text { 19. Simplify low } \\
\text { scale zones }\end{array}$ & $\begin{array}{l}\text { 20. Reduce parking } \\
\text { requirements }\end{array}$ & $\begin{array}{l}21 . \text { Increase } \\
\text { opportunities for } \\
\text { semi-detached } \\
\text { housing }\end{array}$ & $\begin{array}{l}\text { 22. Create } \\
\text { opportunities for } \\
\text { small apartment } \\
\text { buildings }\end{array}$ \\
\hline & $\begin{array}{l}\text { 23. Create } \\
\text { opportunities for } \\
\text { more suites on a } \\
\text { property }\end{array}$ & $\begin{array}{l}\text { 24. Remove zoning } \\
\text { barriers for } \\
\text { medium scale }\end{array}$ & $\begin{array}{l}\text { 25. Integrate urban } \\
\text { design in to Zoning } \\
\text { Bylaw }\end{array}$ & & \\
\hline
\end{tabular}

Table 10: Infill Roadmap Actions (Edmonton, 2018); bolded items are City of Edmonton identified priority actions

The Evolving Infill Project is intended to help Edmonton achieve its large strategic goals and therefore the City developed two measures to determine if this project was meeting its goals: the number of new residential units in mature neighbourhoods as a percentage of all new housing units city-wide and the Residential Housing Diversity Index. Edmonton wants to improve how it monitors and reports infill data by developing new measures for measuring infill development, refining existing measures, and improving the accessibility and clarity of available data in infill (Edmonton, 2018a: 37). Data collected is publicly available and is published online (Edmonton, n.d.d.)

To create a regulatory environment that is conducive to encouraging infill development and to complete several actions from the 2018 Infill Roadmap, Edmonton has made several amendments to its zoning bylaw. On August 20, 2018 City Council approved an amendment to the zoning bylaw that expanded opportunities for secondary suites. Secondary suites became permitted in semi-detached houses, duplexes, and row housing. As well, the minimum lot size requirements for secondary suites was reduced and the maximum floor area for above grade secondary suites was increased (Edmonton, n.d.b). The zoning bylaw was again amended on December 10, 2018 to permit duplex and semi-detached housing forms in its Single Detached Residential (RF1) Zone (Edmonton, 2018b). A final, and significant, amendment to Edmonton's 
zoning bylaw came on August 26, 2019. This amendment redefined multi-unit housing to refer to any development of three or more principle dwellings arranged in any configuration in any number of buildings. Multi-unit housing was then permitted in the Small Scale Infill Development Zone (RF3), the Row Housing Zone (RF5), the Urban Character Row Housing Zone (UCRH), the Low Rise Apartment Zone (RA7), and the Medium Rise Apartment Zone (RA8) (Edmonton, 2019a).

Community outreach has been a key feature of the Evolving Infill Program since its inception in 2013. More than 1000 people took part in a city led conversation about infill and offered their opinions; feedback was used to shape the actions presented in the 2014 Infill Roadmap (Edmonton, 2014: 5). The 2018 Roadmap was created out of a collaborative process between residents, community organizations, the development industry, and the City. The engagement strategy for the 2018 Roadmap was developed at the beginning of the project when the Evolving Infill team met with key stakeholders. Three months of over 30 community engagement events were held at the outset to bring residents, institutions, business, and community organizations into the process. The feedback from these events were used in drafting a technical report and developing the action items for the Roadmap. Another four months of public outreach were conducted in which the public was invited to review and discuss the draft report and actions. During the outreach process, City staff offered many activities and used different techniques to generate ideas, answer questions, teach people about infill, and allow people to learn about other peoples' position on infill (Edmonton, 2018c: 19-24).

To encourage increased high-quality infill in Edmonton, the city held a Missing Middle Infill Design Competition that received 30 submissions from across Canada, the United States, and the United Kingdom. The intent of the competition was to encourage conversations about missing middle housing in Edmonton, increase peoples' awareness of what these housing forms could offer, display how missing middle housing could be used to create novel and contextually sensitive and appropriate housing, and demonstrate how missing middle housing developments could be economically feasible in this market (Edmonton, 2019b). The winning design offered 56 ground related dwellings designed for families, students, and senior citizens. This design took advantage of nearby light rail transit to reduce the number of parking stalls offered and uses the surrounding neighbourhood as inspiration for its physical layout (Edmonton, 2019b: 13). The winner of this competition can purchase the site used for this competition from the city and build its design (Edmonton, 2019b: 3). 
Edmonton has also introduced an Expedited Infill Pilot that will run until the end of 2021. This program offers builders who wish to construct single-detached or semi-detached infill housing within a mature neighbourhood an opportunity to have the permitting process timeline reduced from over 40 days to 21 or fewer days. To be eligible for this program, builders must complete a five-course Builder Education Program to learn about infill, high-standard construction practices, design fundamentals, and communications. If this pilot program is successful, the scope of this project may be expanded to include other housing forms (Edmonton, n.d.c).

\section{CASE StUdy: VANCOUVER'S NoRQUay VILLAGE}

The Norquay Village Neighbourhood Centre Plan in Vancouver represents a community level plan that resulted in zoning changes that will allow increased density through permitting missing middle housing forms (Vancouver, 2010). The Plan is designed to "[increase] housing density" and "[maintain] the distinctive and eclectic character of the neighbourhood" (Vancouver, 2010: 5). While being local in nature, this Plan took direction from the Vancouver CityPlan which seeks to increase neighbourhood housing variety to provide people at different life stages a place to live in their local community and to create lively neighbourhood centres (Vancouver, 2010: 6). Norquay Village is described as a "typical East Vancouver residential neighbourhood” consisting of streets with single-family houses with commercial shops and services located along Kingsway Avenue, a commercial street (Vancouver, 2010: 8).

The houses in Norquay Village were becoming increasingly expensive and out of reach of many young people and first-time buyers (Vancouver, 2010: 8). Objective 4 of the Plan explains that providing more entry-level home ownership opportunities, while retaining the opportunity for rental housing was a priority (Vancouver, 2010: 18). The strategies developed to meet this objective included permitting housing types that are conducive to ownership on one parcel (duplex, rowhouses, stacked townhouses) and allowing for secondary suites in all housing forms. Objective 3 provides that all change brought about through the Plan should be organic, incremental, and long-term. The neighbourhood should not be dramatically reshaped through the development of uniform housing at one time (Vancouver, 2010: 17). This will be achieved by emphasizing housing that can be built on a single lot which does not require land assembly, implementing design guidelines to ensure housing fits the character of the neighbourhood, provide zoning that allows flexibility, and incentivizing retention of character homes (Vancouver, 2010: 17). 
The Norquay Village Neighbourhood Centre Plan emphasizes ground-oriented housing in residential neighbourhoods with a transition to higher density apartments on Kingsway Avenue. Within the residential areas, the Plan seeks to increase the diversity of housing forms while maintaining the character of the existing residential neighbourhood using design guidelines to ensure new housing fits the scale, height, and massing of the existing single-family character (Vancouver, 2010:21). The diverse forms of housing are intended to provide a scale of affordable units, from single-detached and apartment penthouses (most expensive) to duplexes, rowhouses, triplexes, large apartments, and finally small apartments (2010: 22). To achieve this outcome, significant rezoning must occur because most of the residential neighbourhood is zoned to permit only single-detached housing (2010: 24). Proposed zoning permissions for the residential portion of Norquay Village are displayed in Table 11. Since this rezoning was done at a small scale, zoning permissions were created that considered existing block structure, lot configurations, lot sizes, and existing community conditions and was respectful of the existing community character while creating the opportunity for more housing (2010: 23). The new zoning permissions provided owners of character houses incentives to retain these properties and convert them into two- or three-unit multi-family structures. Most of the neighbourhood was rezoned as small/house duplex with only five blocks retaining its original single-detached zoning (Vancouver, 2010: 29).

\begin{tabular}{|l|c|c|c|c|c|}
\hline \multirow{2}{*}{ Housing Type Permitted } & $\begin{array}{c}\text { Small } \\
\text { House/ } \\
\text { Duplex } \\
\text { Zone }\end{array}$ & $\begin{array}{c}\text { Rowhouse } \\
\text { Zone }\end{array}$ & $\begin{array}{c}\text { Stacked } \\
\text { Townhouse } \\
\text { Zone }\end{array}$ & $\begin{array}{c}\text { Apartment } \\
\text { Transition } \\
\text { Zone }\end{array}$ & $\begin{array}{c}\text { Zoning } \\
\text { Unchanged }\end{array}$ \\
\hline Single Detached & $\checkmark$ & $\checkmark$ & $\checkmark$ & $\mathrm{x}$ & $\checkmark$ \\
\hline Duplex & $\checkmark$ & $\checkmark$ & $\mathrm{x}$ & $\mathrm{x}$ & $\mathrm{x}$ \\
\hline Triplex & $\mathrm{x}$ & $\mathrm{x}$ & $\checkmark$ & $\mathrm{x}$ & $\mathrm{x}$ \\
\hline Rowhouse & $\mathrm{x}$ & $\checkmark$ & $\checkmark$ & $\mathrm{x}$ & $\mathrm{x}$ \\
\hline Secondary Suite & $\checkmark$ & $\checkmark$ & $\checkmark$ & $\mathrm{x}$ & $\checkmark$ \\
\hline Stacked Townhouse & $\mathrm{x}$ & $\mathrm{x}$ & $\checkmark$ & $\mathrm{x}$ & $\mathrm{x}$ \\
\hline Character House \\
Conversion & $\checkmark$ & $\checkmark$ & $\checkmark$ & $\mathrm{x}$ & $\mathrm{x}$ \\
\hline Low Rise Apartment & $\mathrm{x}$ & $\mathrm{x}$ & $\mathrm{x}$ & $\checkmark$ & $\mathrm{x}$ \\
\hline
\end{tabular}

Table 11: Norquay Village Proposed Residential Zoning (Vancouver, 2010: 30-43)

The Norquay Village Neighbourhood Centre Plan was created as a collaborative effort between the City of Vancouver, Norquay Village residents, and property and business owners (Vancouver, n.d.). This Plan was approved by Vancouver City Council in 2010 and the zoning amendments were passed in 2016 (Vancouver, n.d.). In addition to the Norquay Village Neigbhourhood Centre Plan, a Public Benefits Strategy, a Public Realm Plan, and guidelines for 
the retention of character houses were developed for Norquay Village residential areas and a Shopping Area Public Realm and Transportation Improvements Plan were developed for the commercial area along Kingsway Avenue. These documents outlined specific improvements for public spaces, streets, protection of trees, and pedestrian only spaces and detailed community needs for a community facility, a linear park, upgrades of existing parks, new childcare spaces, and new affordable housing (Vancouver, n.d.). A 2017 progress update shows, in addition to public realm benefits being provided to the community, the city received 172 development applications to build 31 single-family dwellings, 76 two-family dwellings, 30 multiple dwellings (e.g. stacked townhouses), 17 laneway houses, 3 secondary suites, 13 small houses/duplexes, and 2 'other' (Vancouver, 2017).

\section{LESSONS FOR TORONTO FROM THE CASE STUDIES}

This paper has examined successful and unsuccessful attempts at policy and zoning changes at the state, city, and community level that are intended to increase density within existing communities. The successes and failures of governments in shifting to new policy directions can provide Toronto with lessons on best practices to follow as it considers shifting from 'exclusionary' zoning to 'equitable' zoning in order to increase the supply of land available for missing middle housing. A summary of the case studies and the lessons each provide for Toronto are presented in Table 12 at the end of this section.

The California case study shows that although Weiner's land use reforms were predicted to have positive impacts on unlocking supply capacity and increasing housing, it was politically untenable for several reasons. First, SB 827 was seen as an intrusion of state power into local communities. Despite including provisions for 'local flexibility plans' in SB 50 an ongoing narrative indicated that local communities would lose their power to plan the future of their communities. In Canada provinces have the constitutional authority to directly influence a municipality's planning policy. The Government of Ontario can unilaterally impose zoning reform on a municipality utilizing a Minister's zoning order. However, while politically feasible, this may have the optics of being a draconian measure. Ontario may also influence a municipality's land use planning through policy documents. The 2020 update to the Provincial Policy Statement (PPS) now includes language indicating that:

"healthy, liveable and safe communities are sustained by ... accommodating an appropriate affordable and market-based range and mix of residential types (including single-detached, additional residential units, [and] multi-unit housing" (Ontario, 2020, emphasis added to indicate changes from previous PPS). 
The PPS has also been amended to define 'housing options' and expanded the definition of 'residential intensification' to include "development and introduction of new housing options within previously developed areas" (Ontario, 2020, emphasis in original). These changes to the PPS indicate that the provincial government may be beginning to direct municipalities towards increasing density within established communities through provincial policy. A second reason that SB 50 was politically untenable is that it contained much vague language defining a 'sensitive' community. This would result in some at risk communities being excluded from the 'equitable communities incentive' exclusions. Vague language such as this contributed to a narrative that these attempts at state-wide zoning reform were a 'give-away' to developers that would not help communities. The inability of Weiner and advocates for zoning reform to effectively counter this argument and address displacement concerns, inclusionary housing issues, community rights, tenant protections, and housing affordability was a third reason why these bills were politically untenable.

Portland's Residential Infill Program seeks to reduce housing sizes, increase housing supply and diversity, and increase housing affordability through zoning reform. This will be achieved by permitting more housing types in areas currently zoned to allow only single detached housing. Portland will regulate building size and massing through floor to area ratios; this will allow Portland to incentivize higher density housing forms by providing density bonuses, through increased FAR, in developments that produce missing middle housing. The Residential Infill Program has been ongoing since the fall of 2015; this contrasts with California's attempts to reform zoning statewide in one legislative sitting. Throughout the process of developing this program community input has been solicited and used to refine policies. This Program, which has taken a slower approach to zoning reform than that attempted in California, has also been able to study its impacts on residential displacement and is currently being finalized alongside the creation of an Anti-Displacement Plan.

The Minneapolis 2040 Plan explicitly acknowledges that past zoning was founded upon racial and class animus and contributed to segregation, unequal distribution of resources, and growth of wealth differences along race and class lines. Zoning reform in Minneapolis aimed to create zoning that would address housing supply, affordability, and segregation. This was part of a city-wide reform aimed at addressing historical injustices that were codified in City policy. The zoning reform Minneapolis opted for was to increase housing permissions and permitted density across the city. This included permitting up to triplexes in areas that previously allowed only single-detached houses. Like Portland, the creation of the Minneapolis 2040 Plan was a long-term project that engaged the community. To ensure that communities that were historically 
marginalized in local politics were heard, innovative outreach techniques were developed and used. Minneapolis also recognized the limitations of the market to generate affordable missing middle housing. To incubate this market segment and generate affordable units, the city funded the Missing Middle Housing Pilot project.

Seattle responded to its need for more housing with the Mandatory Housing Affordability (MHA) program. Unlike Portland and Minneapolis which upzoned large swaths of land to permit higher density ground-related housing, Seattle only upzoned lands in its MHA areas to be consistent with the city's growth policies that direct growth to Urban Villages and Urban Centres. Thus, the MHA program only resulted in rezoning about 6 percent of areas previously zoned for single-detached housing; most upzoning occurred in areas in which high density development was already permitted. In return for the increase in permitted density in MHA areas, the city requires developers to make contributions for affordable housing through provision of units or through a cash payment. However, recent reporting by the Seattle Planning Commission suggests that Seattle continues to experience an inequitable distribution of development in the city with Urban Villages receiving most growth while single-family areas receiving very little. The MHA program, which was created to align with Seattle's comprehensive plan growth policies, is intended to provide affordable housing growth in areas that already permit density and does not provide the policy direction needed to significantly expand missing middle housing. This points to the need for high level municipal policy to be reformed to be supportive of increasing density in existing single-detached neighbourhoods before other plans that seek to further the goals of increasing density in these neighbourhoods can be effective.

Edmonton's Evolving Infill Project provides an example of zoning reform in a large Canadian market that seeks to promote infill development in its established and mature neighbourhoods. Like Toronto, Edmonton's mature neighbourhoods are seeing population decline. Edmonton is attempting to solve this problem by creating the regulatory environment in which new, diverse housing can be added into these neighbourhoods in order to support them and contribute to their stability. The Evolving Infill Project is a long-term project that had its origins in 2010 with Edmonton's updated Municipal Comprehensive Plan and the City's recognition of the need to promote infill development. The Project has released two Infill Roadmaps that contain concrete actions for the city to take to achieve its vision. The Project has also collaborated with the community in developing its actions and used feedback to refine them. Significant outcomes of this Project were zoning reforms which opened established neighbourhoods to increased density by permitting missing middle housing forms. The City also permitted increased density through most of the city by permitting semi-detached housing in 
areas previously zoned for single-detached housing. Edmonton held a Missing Middle Infill Design Competition to generate discussion on what missing middle housing can look like in established neighbourhoods, to change peoples' opinions on missing middle housing, and to prove its economic feasibility in the Edmonton market. Edmonton also implemented a pilot program to expedite planning approvals for some housing forms in mature neighbourhoods. The success of the Evolving Infill Project is important to Edmonton and the city has developed measures to gauge if its goals are being achieved through this project. The city also monitors infill develop throughout the city and continuously assesses the best ways to collect data on infill and to report this data.

Norquay Village shows how zoning reform can be accomplished at a neighbourhood scale to permit more housing forms and increase the number of households a community can accommodate in order to develop housing that is within reach of households who require different sizes and price points. By developing a plan at a community scale, zoning permissions can be tailored to be respectful of existing conditions and permit flexibility to allow the community and the city to meet their long-term goals. This example shows how design guidelines can be implemented to guide development in a neighbourhood to ensure that new development complements what already exists. The Norquay Village Neighbourhood Centre Plan was developed along other plans which articulated the community's need for public benefits and improved public spaces; this shows how upzoning to allow greater housing diversity and density can be linked with community improvements so that existing residents gain benefit from redevelopment. 


\begin{tabular}{|c|c|c|c|c|}
\hline \multicolumn{5}{|c|}{ Summary Table of Case Studies } \\
\hline Case Study & $\begin{array}{l}\text { Time } \\
\text { frame }\end{array}$ & Goals & Actions & Key Lessons for Toronto \\
\hline \multirow{2}{*}{ California } & $\begin{array}{l}2018- \\
2019\end{array}$ & \multirow{2}{*}{$\begin{array}{l}\text { Encourage housing } \\
\text { production }\end{array}$} & $\begin{array}{l}\text {-Override local zoning to provide density bonuses for } \\
\text { development near transit }\end{array}$ & \multirow{2}{*}{$\begin{array}{l}\text {-Higher levels of government may impose } \\
\text { requirements on municipalities } \\
\text {-Need to generate political support by } \\
\text { addressing community concerns }\end{array}$} \\
\hline & $\begin{array}{l}2019- \\
2020 \\
\end{array}$ & & $\begin{array}{l}\text {-Provide waiver from local zoning for multifamily } \\
\text { developments near transit }\end{array}$ & \\
\hline Portland & $\begin{array}{l}\text { 2015- } \\
\text { ongoing }\end{array}$ & $\begin{array}{l}\bullet \text { Reduce housing size } \\
- \text { Increase housing supply } \\
- \text { Reduce housing costs }\end{array}$ & $\begin{array}{l}\text { - Residential Infill Program } \\
\text {-Public outreach and stakeholder engagement } \\
\text {-Zoning reforms to permit missing middle housing } \\
\text { through most of the city's single-detached } \\
\text { neighbourhoods }\end{array}$ & $\begin{array}{l}\text {-Importance of long-term community } \\
\text { engagement } \\
\text {-Consideration of displacement impacts of } \\
\text { rezoning }\end{array}$ \\
\hline Minneapolis & $\begin{array}{l}2016- \\
2019\end{array}$ & $\begin{array}{l}\bullet \text { Encourage development } \\
\text { of multifamily housing } \\
\text { throughout the city to } \\
\text { address racial and class } \\
\text { inequity } \\
\text {-Ensure all residents have } \\
\text { access to affordable } \\
\text { quality housing }\end{array}$ & $\begin{array}{l}\text {-Permitting increased density throughout the entire } \\
\text { city with single-family areas permit up to three } \\
\text { dwelling units per lot } \\
\text { - Long-term community engagement using novel } \\
\text { techniques to generate support for the project and to } \\
\text { address community concerns } \\
\text { - Established the Missing Middle Housing Pilot Program } \\
\text { to encourage development of missing middle housing. }\end{array}$ & $\begin{array}{l}\text {-The racial and class inequities inherent in } \\
\text { planning policies should be addressed } \\
\text {-Programs to support goals may need to be } \\
\text { implemented }\end{array}$ \\
\hline Seattle & $\begin{array}{l}2014- \\
2019\end{array}$ & $\begin{array}{l}- \text { Produce } 50,000 \text { new } \\
\text { housing units with } 20,000 \\
\text { of these being affordable }\end{array}$ & $\begin{array}{l}\text {-Increased zoning permissions in Urban Villages in } \\
\text { exchange for affordable housing contributions from } \\
\text { developers. }\end{array}$ & $\begin{array}{l}\text {-City-wide policy must be supportive of } \\
\text { encouraging density in single-detached } \\
\text { neighbourhoods } \\
\text {-Use density bonuses to generate affordable } \\
\text { housing }\end{array}$ \\
\hline Edmonton & $\begin{array}{l}2013- \\
2019\end{array}$ & $\begin{array}{l}\bullet \text { Increase residential } \\
\text { density in mature } \\
\text { neigbhourhoods to } \\
\text { address declining } \\
\text { population } \\
\text {-Change land extensive } \\
\text { growth patterns }\end{array}$ & $\begin{array}{l}\text {-Establish action items for the city to complete to } \\
\text { successfully create necessary conditions to encourage } \\
\text { missing middle housing } \\
\text {-Zoning by-law amendments to increase residential } \\
\text { housing density } \\
\text { - Community outreach to generate discussion and } \\
\text { ideas } \\
\text {-Missing Middle Infill Design Competition and the } \\
\text { Expedited Infill Pilot to encourage development of } \\
\text { missing middle housing } \\
\text {-Monitoring of impacts of policy and assessing this } \\
\text { against strategic goals. }\end{array}$ & $\begin{array}{l}\text {-Monitoring and evaluation of policy and } \\
\text { programs } \\
\text {-Programs may have to be re-evaluated and } \\
\text { changed based on results } \\
\text {-Zoning changes can occur in several phases } \\
\text {-Programs to support goals may need to be } \\
\text { implemented }\end{array}$ \\
\hline $\begin{array}{l}\text { Norquay } \\
\text { Village }\end{array}$ & $\begin{array}{l}2010- \\
2016\end{array}$ & $\begin{array}{l}\bullet \text { Increase residential } \\
\text { density while maintaining } \\
\text { neighbourhood character }\end{array}$ & $\begin{array}{l}\text {-Zoning reform to permit increased density } \\
\text { - Creation of design guidelines to ensure that new } \\
\text { housing is of the same scale and character as existing } \\
\text { structures } \\
\text {-Collaboration between the City, residents, property } \\
\text { owners, and business } \\
\text { - Created other plans that provided benefits to } \\
\text { Norquay Village }\end{array}$ & $\begin{array}{l}\text {-Design guidelines can be used to ensure } \\
\text { architectural character of a community is } \\
\text { preserved } \\
\text { - Rezoning can be tied to a greater re-envisioning } \\
\text { of a community and provision of community } \\
\text { benefits. }\end{array}$ \\
\hline
\end{tabular}

Table 12: Case Studies Summary 


\section{RECOMMENDATIONS FOR TORONTO}

Before providing recommendations for Toronto, it is prudent to return to the three questions posed by Schuetz (2019) when evaluating zoning and recommending changes. First, is the housing market producing enough units to meet demand? As shown earlier in this paper, supply is unable to meet demand and is causing housing prices to rise. Second, is new housing being built in the locations where people want to live? Again, the answer to this question is no. Torontonians have a strong preference for ground-related housing but only $10.8 \%$ of housing completions in Toronto between 2012 and 2018 were for these housing types. The regions of Durham, York, Peel, and Halton produced about 80,000 more ground-relating housing units that Toronto over the same timer period (Table 4). Finally, is the market providing a diversity of housing choices that meet household sizes and budgets? Again, the answer to this question is no. Housing is, or is becoming, unaffordable for many Torontonians. With almost $90 \%$ of housing units produced between 2012 and 2018 being apartments, Toronto is not producing a diversified housing stock that is accessible and meets the needs of its diverse population. A major impediment to increasing diversity and affordability in Toronto's housing stock is its planning regulations. Not enough land is zoned for ground-related missing middle housing which could provide more affordable housing options; where these housing forms are permitted, the Official Plan often restricts these forms in the name of protection of stable neighbourhoods.

- RECOMMENDATION 1: Toronto must create consistency between and within its planning policies and amend its zoning bylaw and Official Plan to promote housing diversity and infill in stable neighbourhoods.

Current Official Plan and zoning bylaws limit what can be built and where it can be built within Toronto. Policy impacts the ability of the market to respond to changes in demand by increasing supply of needed and desired housing forms. Toronto needs to acknowledge the impacts that its restrictive and exclusionary policies have on housing supply and amend these policies. Official Plan policies that regard 'stable' neighbourhoods as inviolate and direct most of the Toronto's growth to a small portion of its land mass must be revised. Toronto should ensure that OP policies are consistent with Policy 1 from Section 3.2.1 of the OP which states that:

A full range of housing, in terms of form, tenure and affordability, across the City and within neighbourhoods, will be provided and maintained to meet the current and future needs of residents. A full range of housing includes: ownership and rental housing, affordable and mid-range rental and ownership housing, social housing, shared and/or congregate-living housing arrangements, supportive housing, emergency and transitional housing for homeless people and at-risk 
groups, housing that meets the needs of people with physical disabilities and housing that makes more efficient use of the existing housing stock (Section 3-21).

Amending the Official Plan is an important first step in creating the regulatory environment for the expansion of missing middle housing forms in Toronto's stable neighbourhoods. The OP constrains growth in order to protect stable neighbourhoods even when zoning permits a use. As seen in the Seattle case study, high level plans, such as Seattle's Comprehensive Plan or Toronto's $\mathrm{OP}$, require other policy policies to conform to them. If these plans do not permit, or are not supportive, of increasing density in low-density residential neighbourhoods, other plans, policies, or regulations will be unable to encourage increased density in these areas. This is further seen in the previously discussed case of a triplex development being rejected because, even though permitted by zoning, it did not meet stringent requirements established by the OP of respecting the 'prevailing character' of the neighbourhood.

Toronto must also amend its zoning bylaw to permit missing middle housing in lowdensity neighbourhoods that currently do not permit these housing forms (Table 6). Zoning reform must also address parts of the zoning by-law that impact the scale and massing of structures such as height limits, setbacks, lot sizes, and FAR because these can create a building footprint that is unable to accommodate missing middle housing (Wegmann, 2020: 115). Parking requirements, which require a certain number of parking spaces per dwelling unit, can also limit missing middle housing by making multi-unit structures untenable on a site.

While the California and Seattle case studies illustrate attempts at upzoning limited residential areas, Toronto should follow the lead of Portland, Minneapolis, and Edmonton and permit missing middle housing forms over most, if not all, stable neighbourhoods. There are two reasons for this. First, this would reduce barriers to housing construction over large swaths of the city. As mentioned in this paper, the market will only produce housing where land supply, land values, and demand are conducive for development. By opening as much of the city's low-density residential neighbourhoods to increased density, this increases the likelihood of the market finding locations that are suitable for missing middle housing. This reduces that risk that upzoning to increase development permissions results in higher land values without a concomitant increase in the production of missing middle housing. Second, lack of housing supply is a city-wide issue and all neighbourhoods must be involved in creating solutions to this problem. Permitting increased density in all low-density residential neighbourhoods reduces the risk that development will only happen in neighbourhoods that are less affluent and not politically strong. In neighbourhoods where there are concerns about neighbourhood character, the city can work with the community to develop design guidelines, as was done in Norquay Village, to ensure that 
new built form is consistent with what currently exists. Zoning reform to permit increased housing options in low-density neighbourhoods across the city would reduce a barrier to housing construction and allow the market the flexibility to provide smaller, more affordable units in areas that are currently well serviced when there is market demand and when it is financially feasible.

- RECOMMENDATION 2: Toronto must change peoples' opinions of density and missing middle housing by engaging with all segments of Toronto's population and interested groups

A poll conducted by the Home Building Industry and REALTORS (Toronto Regional Real Estate Board, 2018) finds that $87 \%$ of respondents in the GTA indicate it is important for more housing be produced to address housing affordability and that $89 \%$ of respondents from Toronto believe that zoning should be reformed to allow more density; however, over one-third of respondents indicated that they would be opposed to new housing that was greater in density than single-detached homes within 500 metres from their home. Many people have a deep-seated dislike of density. Density conjures images of tall towers and congestion; however, density does not have to mean increased height (CMHC, 2018: 134). Toronto needs to implement a public engagement program to address 'NIMBY' opposition to increasing density within low-density residential area if is to be successful in generating the political wherewithal to implement policy reform. The framing of conversations surrounding missing middle housing, infill, and increased density is critical at the outset of any discussion on this topic. For this reason, Toronto should develop a framing goal that structures conversations on this topic as Edmonton's "how can we welcome more people and new homes into our older neighbourhoods." Furthermore, planning for community improvements and community benefits can be done alongside planning for zoning reform and increases in density, as was done in Norquay Village, so that existing community members will see tangible benefits for themselves as the outcome of the process.

As the case studies in this paper have shown, successful policy reform has been the outcome of multi-year long-term public engagement which was able to show the benefits of incorporating 'gentle density' into existing communities. As well, this needs to be broad based engagement. It cannot only talk to homeowners and members of community organizations. This reifies political and economic inequities within the planning process and gives greater sway to these individuals' opinions. This will mean using innovative engagement techniques designed to bring in groups who are commonly excluded from traditional planning outreach and collaborating with a range of stakeholders including builders, housing advocates, renters, community members, and potential community members. This can be complemented with design competitions that 
create positive conversations about what new missing-middle housing can look like within a stable neighbourhood and dispel fears about loss of community character.

While an important element of the discussion about policy reform to reduce barriers to missing middle housing revolves around concerns about how it will impact community character, the case studies also show that there is significant concern about what impacts up-zoning will on low-income communities and housing affordability. Toronto must address these concerns by conducting studies to understand the impacts of zoning change on displacement and loss of affordable housing; if needed, further policies to provide greater tenant protects and to mitigate loss of affordable units will be required.

\section{- RECOMMENDATION 3: Toronto must consider incentives to ensure that missing middle housing is produced}

Missing middle housing plays an important part in ensuring that people have access to housing that is more affordable than single-detached housing, located in desirable locations, and in a form that is suited to different household formations. Missing middle housing needs to be an important part of Toronto's housing stock and, as has been discussed throughout this paper, Toronto should reduce regulatory barriers to its production. However, zoning reform alone will not guarantee this form of housing is built but is an important first step towards creating the conditions for increasing housing supply (Baca and Lebovits, 2019). Toronto must consider providing incentives to encourage missing middle housing get built in its stable neighbourhoods. Examples of incentivising this type of housing are increases to FAR as seen in Portland's Residential Infill Program, Edmonton's Expedited Infill Pilot, and Minneapolis' Missing Middle Housing Pilot Program.

\section{- RECOMMENDATION 4: Toronto should utilize land capture techniques}

Rezoning to encourage higher density residential development has the potential to produce very little housing but increase land values (Freemark, 2019). Toronto needs to implement land value capture measures to ensure that zoning reform meets its objectives of providing more housing options at prices that are less than single-detached houses. If the primary impact of upzoning is an increase in property values the housing market will become less affordable as home prices and rents increase and builders and developers are required to create 'luxury' units to recoup their increased land value costs. When developing a program to capture any land value increase brought about by zoning change, Toronto must be cognizant of the impacts that land value has on the development potential of a site; if land value capture is too 
aggressive or does not provide flexibility, desirable projects may become financially unfeasible. Most of the case studies presented in this paper did not address capturing increases in land value through rezoning. However, Seattle's MHA program and California's attempts at zoning reform both required contributions of affordable housing units or cash-in-lieu payments in return for increased development permissions. Inclusionary zoning such as this could be a land value capture tool used by Toronto to capture the uplift in land value generated through rezoning. Toronto could also limit the size of redeveloped housing units through rezoning reform as Portland has done. This would disincentivize creating large, expensive homes. Increased development potential could be granted for meeting criteria such as providing additional units and providing units that are affordable. Another option that Toronto could consider is to use Upzone Development Rights (UDR) (Fyall and Casey, 2017). Under UDR, the increased development rights created when properties are rezoned are owned by the municipality. Before a property owner can redevelop a property to take advantage of new zoning permissions, the UDR must be purchased. The municipality may then use these funds to support affordable housing initiatives. Before any land value capture tool is implemented, Toronto must complete an analysis to understand the implications of that tool on land values and the development of missing middle housing within Toronto's established neighbourhoods. 


\section{References Cited}

Alliance for Community Transit. (2020, January 24). RE: SB 50 (Wiener), as amended January 6, 2020 -Oppose Unless Amended. Letter to Scott Wiener. Retrieved from the Alliance for Community Transit website http://allianceforcommunitytransit.org/wpcontent/uploads/2020/02/SB-50-Oppose-Unless-Letter.pdf, accessed March 7, 2020.

Baca, Alex and Hannah Lebovits. (2019, February 5). No, Zoning Reform Isn't Magic. But It's Crucial. CityLab. Accessed from CityLab website: https://www.citylab.com/perspective/2019/o2/zoning-reform-house-costs-yonahfreemark-research/582034/, November 9, 2019.

Baca, Alex, Patrick McAnaney, and Jenny Schuetz (2019, December 4). "Gentle" density can save our neighborhoods. Retrieved from the Brookings Institution website: https://www.brookings.edu/research/gentle-density-can-save-our-neighborhoods, Accessed January 20, 2020.

Beekman, Daniel. (2019, March 18). Seattle upzones 27 neighborhood hubs, passes affordablehousing requirements. Seattle Times. Accessed from Seattle Times website: https://www.seattletimes.com/seattle-news/politics/seattle-upzones-27-neighborhoodhubs-passes-affordable-housing-requirements/, November 9, 2019

Been, Vicki, Ingrid Gould Ellen, and Katherine O’Regan. (2018). Supply Skepticism: Housing Supply and Affordability. Report prepared for NYU Furman Centre. Retrieved from the Furman Centre website, https://furmancenter.org/files/Supply_Skepticism_-_Final.pdf, Accessed February 16, 2020.

Bertaud, Alain. (2018). Order without Design. Cambridge, MA: MIT Press.

Bruekner, Jan. (2011). Lectures on Urban Economics. Cambridge, MA: MIT Press.

Bureau of Planning. (1991). Portland Zoning Code. Current as of March 1, 2019. City of Portland. Accessed from City of Portland website: https://www.portlandoregon.gov/citycode/28197, March 8, 2020.

Bureau of Planning and Sustainability [BPS]. (2015). Comprehensive Plan Update: Growth Scenarios Report. City of Portland. Accessed from City of Portland website: https://www.portlandoregon.gov/bps/article/531170, November 7, 2019.

Bureau of Planning and Sustainability [BPS]. (2019a). Residential Infill Project: An Update to Portland's Single-Dwelling Zoning Rules. Volume 1: Staff Report and Map Amendments. Recommended Draft August 2019. City of Portland. Accessed from City of Portland website: https://www.portlandoregon.gov/bps/article/738843, November 7, 2019.

Bureau of Planning and Sustainability [BPS]. (2019b). Residential Infill Project: An Update to Portland's Single-Dwelling Zoning Rules. Appendix B: Displacement Risk and Mitigation. Recommended Draft February 2019. City of Portland. Accessed from City of Portland website: https://beta.portland.gov/sites/default/files/201912/vol_3_appendix_b_displacement_risk_and_mitigation.pdf, April 2, 2020. 
California Department of Housing and Community Development [CDHCD]. (2018, February). California's Housing Future: Challenges and Opportunities. Final Statewide Housing Assessment 2025. Retrieved from the California Department of Housing and Community Development website https://www.hcd.ca.gov/policy-research/plansreports/docs/SHA_Final_Combined.pdf, accessed March 4, 2020.

Canadian Centre for Economic Analysis [CCEA]. (2019). Toronto Housing Market Analysis: From Insight to Action. Report prepared for the Affordable Housing Office of the City of Toronto. Accessed from City of Toronto website: https://www.toronto.ca/legdocs/mmis/2019/ph/bgrd/backgroundfile-124480.pdf, accessed November 5, 2019.

Canadian Housing and Mortgage Corporation [CMHC]. (n.d.). Housing Completions: By Dwelling Type. Toronto Census Metropolitan Area [Time Series: 2012-2018]. Accessed from the CMHC website https://wwwo3.cmhc-schl.gc.ca/hmippimh/\#TableMapChart/2270/3/Toronto+CMA, retrieved February 8, 2020.

Canadian Housing and Mortgage Corporation [CMHC]. (2018). Examining Escalating House Prices in Large Canadian Metropolitan Centres. Retrieved from the CMHC website https://assets.cmhcschl.gc.ca/sf/project/cmhc/pdfs/content/en/69262.pdf?rev=2a923257-c691-4968-b2f1od91cd13624e, accessed March 12, 2020.

Canadian Housing and Mortgage Corporation [CMHC]. (2019). Identifying Core Housing Need. Retrieved from the CMHC website https://www.cmhc-schl.gc.ca/en/data-andresearch/core-housing-need/identifying-core-housing-need, accessed April 3, 2020.

Canadian Real Estate Association. (n.d.). MLS Home Price Index. Retrieved from the Canadian Real Estate Association website https://www.crea.ca/housing-market-stats/mls-home-priceindex/hpi-tool/, accessed April 3, 2020.

Cash, Anna, Miriam Zuk, and Ian Carlton. (2019, April 15). Upzoning California: What are the Implications of SB 50 for Bay Area Neighborhoods? Retrieved from the Urban Displacement Project website https://www.urbandisplacement.org/blog/upzoning-california-what-areimplications-sb-50-bay-area-neighborhoods, accessed March 8, 2020.

City of Toronto. (n.d.). Zoning by law 569 wgs84-2019.shp [Data file]. Current as of January 9, 2020. Retrieved from the City of Toronto Open Data Portal https://open.toronto.ca/dataset/zoning-by-law/, accessed March 1, 2020.

City of Toronto. (2013). Zoning By-law: By-law No. 569-2013. Consolidation as of July 15, 2019. Retrieved from the City of Toronto website https://www.toronto.ca/wpcontent/uploads/2018/07/97ec-City-Planning-Zoning-Zoning-By-law-Part-1.pdf, accessed March 1, 2020.

City of Toronto. (2015). Toronto Official Plan. Consolidation as of February 2019. Retrieved from City of Toronto website: https://www.toronto.ca/city-government/planningdevelopment/official-plan-guidelines/official-plan/, accessed November 1, 2019. 
City of Toronto. (2019, July 16). Expanding Housing Options in Toronto- Tackling the Missing Middle and the 'Yellowbelt'. Item MM9.36. Accessed from City of Toronto website: http://app.toronto.ca/tmmis/viewAgendaItemHistory.do?item=2019.MM9.36, September 29, 2019.

Clayton, Frank and Kelly Irish. (2017). Overriding Preference for Ground-Related Housing by GTA Millennials and Other Recent and Prospective Buyers. Centre for Urban Research and Land Development. Ryerson University. Toronto, ON.

Clayton, Frank and Diana Petramala. (2019). A Strategy for Significantly Increasing the Supply of "Missing Middle" Housing in the City of Toronto. Centre for Urban Research and Land Development. Ryerson University. Toronto, ON.

The Centre for Housing Policy. (n.d.). "Don't Put it Here!”: Does Affordable Housing Cause Nearby Property Values to Decline? Retrieved from the Furman Centre website https://furmancenter.org/files/media/Dont_Put_It_Here.pdf, accessed March 4, 2020.

Community Planning and Economic Development [CPED]. (n.d.). Allowing Up to 3-unit Buildings in Lower-Intensity Districts, Related Development Standards, and Limits on Lot Combinations. City of Minneapolis. Retrieved from City of Minneapolis website: http://www.minneapolismn.gov/cped/planning/WCMSP-220319, accessed November 10, 2019.

Community Attributes Inc. (2016). Technical Memorandum. Accessed from City of Seattle website:

http://www.seattle.gov/Documents/Departments/HALA/Policy/2016_1129\%20CAI\%20HA LA\%20Economic\%20Analysis\%2oSummary\%2oMemorandum.pdf, November 9, 2019.

Community Planning and Economic Development [CPED]. (2019, October 25). Minneapolis 2040 - The City's Comprehensive Plan. City of Minneapolis. Retrieved from City of Minneapolis website: https://minneapolis2040.com/media/1488/pdf_minneapolis2040.pdf, accessed November 10, 2019.

Cresswell, Neil. (2019, February 11). Staff Report: Committee of Adjustment Application. File No: A0919/18EYK. Accessed from spacing.ca website: http://spacing.ca/toronto/wpcontent/uploads/sites/4/2019/03/54_westhampton-staff_report.pdf, February 28, 2020.

Cullingworth, J. Barry. (1987). Urban and Regional Planning in Canada. New Brunswick and Oxford: Transaction Books.

Dougherty, Conor. (2020, February 16). Every Problem In America Is a Housing Problem. New York Times, Late Edition. p. BU.1. Retrieved from http://ezproxy.lib.ryerson.ca/login?url=https://search.proquest.com/docview/2355478015 ?accountid=13631, accessed March 4, 2020.

Edmonton. (n.d.a). Residential Infill. Retrieved from the City of Edmonton Infill website https://www.cityofedmontoninfill.ca/, accessed March 11, 2020. 
Edmonton. (n.d.b). Expanding Opportunities for Secondary Suites. Retrieved from the City of Edmonton https://www.edmonton.ca/city_government/urban_planning_and_design/zoning-forsuites.aspx, accessed March 11, 2020.

Edmonton, (n.d.c). Supporting Materials: Infill Builders Permit Process Status - Expedited Infill Pilot. Retrieved from the City of Edmonton website http://sirepub.edmonton.ca/sirepub/agdocs.aspx?doctype=agenda\&itemid=74083, accessed March 11, 2020.

Edmonton, (n.d.d). Growth Analysis. Retrieved from the City of Edmonton website https://www.edmonton.ca/city_government/urban_planning_and_design/growthanalysis.aspx, accessed March 11, 2020.

Edmonton. (2010). The Way We Grow: Municipal Development Plan. Bylaw 15100. Retrieved from the City of website https://www.edmonton.ca/city_government/documents/PDF/MDP_Bylaw_15100.pdf, accessed March 11, 2020.

Edmonton. (2014). Edmonton's Infill Roadmap: A Two Year Work Plan to Advance Infill. Retrieved from the City of Edmonton website https://www.edmonton.ca/city_government/documents/Infill_Roadmap.pdf, accessed March 11, 2020.

Edmonton. (2018a). Infill Roadmap 2018: Welcoming More People and New Homes into Edmonton's Older Neighbourhoods. Retrieved from the City of Edmonton website https://www.cityofedmontoninfill.ca/public/download/documents/48322, accessed March 11, 2020.

Edmonton. (2018b). Charter Bylaw 18638 Amendment No. 2697. Retrieved from the City of Edmonton website http://sirepub.edmonton.ca/sirepub/cache/2/jamgpimefg33ghq1vpwjlizg/8047240311202 002490327.PDF, accessed March 11, 2020.

Edmonton. (2018c). What we Heard. Evolving Infill: Stakeholder Engagement Results. Retrieved from the City of Edmonton website https://www.cityofedmontoninfill.ca/public/download/documents/46713, accessed March 11, 2020.

Edmonton. (2019a). Missing Middle Zoning Review: Summary of Changes to Zoning Bylaw 12800. Retrieved from the City of Edmonton website https://www.edmonton.ca/city_government/documents/PDF/MissingMiddleZoningSumm aryGuide.pdf, accessed March 11, 2020.

Edmonton. (2019b). 2019 'Missing Middle' Infill Design Competition Awards. Retrieved from the City of Edmonton website https://www.edmonton.ca/residential_neighbourhoods/PDF/2019_Infill_Design_Competi tion_Award_Booklet.pdf, accessed March 11, 2020.

Einstein, Katherine Levine. (2019). The Privileged Few: How Exclusionary Zoning Amplifies the Advantaged and Blocks New Housing-and What We Can Do About It. Urban Affairs Review. DOI: $10.1177 / 1078087419884644$ 
Fischel, William A. (2004). An Economic History of Zoning and a Cure for its Exclusionary Effects. Urban Studies. 41(2): 317-340.

Fisher, Ernest M., James C. Downs, Jr., Howard G. Brunsman, Donald S. Thompson, and Arthur M. Weimer. (1949). Panel III: Measuring Effective Demand in the Housing Market. Land Economics 25(1): 103-115.

Freemark, Yonah. (2019). Upzoning Chicago: Impacts of a Zoning Reform on Property Values and Housing Construction. Urban Affairs Review. https://doi.org/10.1177/1078087418824672

Frew, James R., G. Donald Jud and Tony R. Wingler. (1990). The Effects of Zoning on Population and Employment Density. Journal of Real Estate Finance and Economics 3: 155-163.

Fyall, Rachel, and Alexander Casey. (2017). Urbanizing for Equity: Harnessing Upzones as a Redistributive Policy Tool. Cityscape: A Journal of Policy Development and Research 19(2): 9-19.

Glaeser, Edward L., and Joseph Gyourko. (2002). The Impact of Zoning on Housing Affordability. Working Paper 8835. Cambridge, MA: National Bureau of Economic Research. Accessed September 27, 2019. https://www.nber.org/papers/w8835

Glaeser, Edward L., Joseph Gyourko and Raven E. Saks. (2006). Urban growth and housing supply. Journal of Economic Geography. 6: 71-89.

Goetz, Edward G. (2019). Democracy, Exclusion, and White Supremacy: How Should We Think About Exclusionary Zoning?. Urban Affairs Review. DOI: 10.1177/1078087419886040

Harrison, Peter and Henry Kraemer. (2019, May). Homes for All: The Progressive 2020 Agenda for Housing. Retrieved from the Data for Progress website: https://filesforprogress.org/reports/homes_for_all.pdf, Accessed March 1, 2020.

HB 2001, 2019 Regular Session (Oregon 2019). Retrieved from Oregon Legislative Information website https://olis.leg.state.or.us/liz/2019R1/Measures/Overview/HB2001， accessed March 8, 2020.

Hertel, Sean and Blair Scorgie. (2019). "Supply, Demand, and Demographics." In House Divided: How the Missing Middle Will Solve Toronto's Housing Crisis, edited by John Lorinc, Alex Bozikovic, Cheryll Case, and Annabel Vaughan. Pages 79-81. Toronto, ON: Coach House Books.

Housing Rights Committee of San Francisco [HRCSF]. (2019, April 17). No to SB 50. No to displacing low-income, working class tenants! Retrieved from the Housing Rights Committee of San Francisco website http://hrcsf.org/2019/04/17/no-to-sb-50-no-to-displacing-lowincome-working-class-tenants/, accessed March 8, 2020.

Hsieh, Chang-Tai and Enrico Moretti. (2015). Why Do Cities Matter? Local Growth and Aggregate Growth. Kreisman Working Paper on Housing Law and Policy No. 30. Accessed from Chicago Unbound website: https://chicagounbound.uchicago.edu/cgi/viewcontent.cgi?article=1045\&context=housing law_and_policy, February 28, 2020. 
Ihlandeldt, Keith. (2019). Not In My Neighborhood: The Effects of Residential Rentals on SingleFamily Home Values. Retrieved from Ihlanfeldt.com: https://ihlanfeldt.com/wpcontent/uploads/2019/07/Not-In-My-Neighborhood-The-Effects-of-Residential-Rentalson-Single-Family-Home-Values.pdf, Accessed February 25, 2020.

Imbroscio, David. (2019). Rethinking Exclusionary Zoning or: How I Stopped Worrying and Learned to Love It. Urban Affairs Review. DOI: 10.1177/1078087419879762

Jaffe, Eric. (2015, May 11). The High Cost of Residential Parking. CityLab. Retrieved from CityLab website: https://www.citylab.com/solutions/2015/05/how-parking-keeps-your-rent-toodamn-high-in-2-charts/392894/, accessed March 9, 2020

Levine, Jonathan. (2006). Zoned Out: Regulation, Markets, and Choices in Transportation and Metropolitan Land-Use. Washington DC: Resources For the Future.

Livable California. (n.d.a). How SB 5o Works to Destroy Thriving Neighborhoods. Retrieved from Livable California website https://www.livablecalifornia.org/sb-50-impact-analysis/, accessed March 7, 2020.

Livable California. (n.d.b). In 2019 We Opposed SB 50, SB 330, SB 59, AB 68 \& AB 1487. Retrieved from Livable California website https://www.livablecalifornia.org/portfolio-items/in-2019we-opposed-sb-50-sb-330-sb-592-ab-68-ab-1487/?portfolioCats=60, accessed March 9, 2020.

Lorinc, John. (2019). "Introduction: The Stability Trap.” In House Divided: How the Missing Middle Will Solve Toronto's Housing Crisis," edited by John Lorinc, Alex Bozikovic, Cheryll Case, and Annabel Vaughan. Pages 10-20. Toronto, ON: Coach House Books.

Lorinc, John., Alex Bozikovic, Cheryll Case, and Annabel Vaughan (eds.). (2019). House Divided: How the Missing Middle Will Solve Toronto's Affordability Crisis. Coach House Books: Toronto, ON.

Mark, Jonathan H. and Michael A. Goldberg. (1986). A Study of the Impacts of Zoning on Housing Values over Time. Journal of Urban Economics. 20: 257-273.

Meslin, Gil. (2019). "A City of Houses.” In House Divided: How the Missing Middle Will Solve Toronto's Housing Crisis, edited by John Lorinc, Alex Bozikovic, Cheryll Case, and Annabel Vaughan. Pages 64-68. Toronto, ON: Coach House Books.

Minneapolis. (2019a). City Council takes final action on Minneapolis 2040, the City's Comprehensive Plan. Retrieved from City of Minneapolis website: http://news.minneapolismn.gov/2019/10/25/city-council-takes-final-action-minneapolis2040-citys-comprehensive-plan/, accessed November 10, 2019.

Minneapolis. (2019b). Ordinance No. 2019-048. Retrieved from City of Minneapolis website: https://lims.minneapolismn.gov/Download/MetaData/15355/2019-048_Id_15355.pdf, accessed March 9, 2020.

Minneapolis. (2019c). Missing Middle Housing Pilot Program (2019-00599). Retrieved from City of Minneapolis website: https://lims.minneapolismn.gov/File/2019-00599, accessed March 9, 2020. 
Minneapolis. (2019d). Missing Middle Housing Pilot Program (RCA-2019-00552). Retrieved from City of Minneapolis website: https://lims.minneapolismn.gov/RCA/4361, accessed March 9, 2020.

Minneapolis. (2019, May 1). Missing Middle Housing Pilot. Retrieved from City of Minneapolis website:

https://lims.minneapolismn.gov/Download/RCA/9171/Missing\%2oMiddle\%2oHousing\%2 oPilot\%20Program\%20Presentation.pdf, accessed March 9, 2020.

Minneapolis. (2020a). Land sale: Missing Middle Housing Pilot Program lot sales and funding recommendations (RCA-2020-00156). Retrieved from City of Minneapolis website: https://lims.minneapolismn.gov/RCA/5635, accessed March 9, 2020.

Minneapolis. (2020b). Land sale: Missing Middle Housing Pilot Program lot sales and funding recommendations (2020-00239). Retrieved from City of Minneapolis website: https://lims.minneapolismn.gov/File/2020-00239, accessed March 9, 2020.

Missing Middle Housing. (n.d.). Retrieved from https://missingmiddlehousing.com/, accessed March 5, 2020.

Ontario. (2019). A Place to Grow: Growth Plan for the Greater Golden Horseshoe. Retrieved from the Government of Ontario website https://files.ontario.ca/mmah-greater-goldenhorseshoe-place-to-grow-english-15may2019.pdf, accessed February 2, 2020.

Ontario. (2020). Provincial Policy Statement, 2020. Retrieved from the Government of Ontario website https://files.ontario.ca/mmah-provincial-policy-statement-2020-accessible-finalen-2020-02-14.pdf, accessed April 1, 2020.

Ontario Ministry of Finance. (2019). Ontario Population Projections, 2018-2046. Retrieved from the Government of Ontario website https://www.fin.gov.on.ca/en/economy/demographics/projections/projections20182046.pdf, accessed February 2, 2020.

Opticos Design Inc. (n.d.). Missing Middle Housing. Retrieved from the Missing Middle Housing website https://missingmiddlehousing.com/, accessed March 4, 2020.

Pendall, Rolf, Robert Puentes, and Jonathan Martin. (2006). From Traditional to Reformed: A Review of the Land Use Regulations in the Nation's 50 largest Metropolitan Areas. Metropolitan Policy Program. The Brookings Institution. Washington, DC. Retrieved from The Brookings Institution website, https://www.brookings.edu/wpcontent/uploads/2016/06/20060802_Pendall.pdf, Accessed March 2, 2020.

Pendall, Rolf. (2019). Growth + Climate Emergency: We're Already Too Late Getting Ready. Exclusionary Zoning Makes Matters Worse. Urban Affairs Review. DOI: $10.1177 / 1078087419889181$

Petramala, Diana and Frank Clayton. (2018). Millennials in the Greater Toronto and Hamilton Area: A Generation Stuck in Apartments? Centre for Urban Research and Land Development. Ryerson University. Toronto, ON. 
Portland. (n.d.). Housing Opportunity Initiative. Retrieved from the City of Portland website (beta) https://beta.portland.gov/bps/housing-opportunity-initiative, Accessed March 8, 2020.

Portland. (2020, January 21). City Council hears lots of public testimony on the Residential Infill Project. Retrieved from the City of Portland website (beta) https://beta.portland.gov/bps/rip/news/2020/1/21/city-council-hears-lots-publictestimony-residential-infill-project, Accessed March 8, 2020.

Portland. (2020, February 14). City Council gives RIP project staff direction on amendment concepts. Retrieved from the City of Portland website (beta) https://beta.portland.gov/bps/rip/news/2020/2/14/city-council-gives-rip-project-staffdirection-amendment-concepts, accessed March 8, 2020.

Saiz, Albert. (2010). The Geographic Determinants of Housing Supply. The Quarterly Journal of Economics. 125(3): 1253-1296.

SB 50, California Legislature- 2019-2020 Regular Session (California 2018). Retrieved from California Legislative Information website https://leginfo.legislature.ca.gov/faces/billNavClient.xhtml?bill_id=201920200SB50, accessed March 7, 2020.

SB 827, California Legislature, 2017-2018 Regular Session (California 2018). Retrieved from California Legislative Information website https://leginfo.legislature.ca.gov/faces/billNavClient.xhtml?bill_id=201720180SB827, accessed March 7, 2020.

Schuetz, Jenny. (2018, December 12). Minneapolis 2040: The most wonderful plan of the year. Retrieved from the Brookings Institution website: https://www.brookings.edu/blog/theavenue/2018/12/12/minneapolis-2040-the-most-wonderful-plan-of-the-year/, Accessed March 9, 2020.

Schuetz, Jenny. (2019, October 31). Is zoning a useful tool or a regulatory barrier. Retrieved from the Brookings Institution website: https://www.brookings.edu/research/is-zoning-a-usefultool-or-a-regulatory-barrier, Accessed January 20, 2020.

Schuetz, Jenny. (2020). To improve housing affordability, we need better alignment of zoning, taxes, and subsidies. Retrieved from the Brookings Institution website: https://www.brookings.edu/policy2020/bigideas/to-improve-housing-affordability-weneed-better-alignment-of-zoning-taxes-and-subsidies/, Accessed January 20, 2020.

Scorgie, Blair. (2019). "Dissecting Official Plan Amendment 320." In House Divided: How the Missing Middle Will Solve Toronto's Housing Crisis," edited by John Lorinc, Alex Bozikovic, Cheryll Case, and Annabel Vaughan. Pages 96-102. Toronto, ON: Coach House Books.

Seattle. (2015). Housing Seattle: A Roadmap to an Affordable and Livable City. An Action Plan to Address Seattle's Affordability Crisis. Accessed from City of Seattle website: https://murray.seattle.gov/wp-content/uploads/2015/o7/HALA_ActionPlan_2015.pdf, November 9, 2019. 
Seattle (2018). Mandatory Housing Affordability (MHA): Citywide Implementation. Director's Report and Recommendation. Accessed from City of Seattle website: https://www.seattle.gov/Documents/Departments/HALA/Policy/Directors_Report_MHA_ Citywide.pdf, November 9, 2019.

Seattle (2019). How MHA Works. Accessed from City of Seattle website: https://www.seattle.gov/Documents/Departments/HALA/Policy/How_MHA_Works.pdf, November 9, 2019.

Seattle Planning Commission. (2018). Neighbourhoods for All: Expanding Housing Opportunity in Seattle's Single-Family Zones. Accessed from City of Seattle website: https://www.seattle.gov/Documents/Departments/HALA/Policy/How_MHA_Works.pdf, November 9, 2019.

Seattle Planning Commission. (2020). Evolving Seattle's Growth Strategy: A White Paper by the Seattle Planning Commission. Accessed from City of Seattle website: https://www.seattle.gov/Documents/Departments/SeattlePlanningCommission/SPC\%20Gr owth\%20Strategy\%20White\%2oPaper\%201072020(o).pdf, March 5, 2020.

Sierra Club. (2018, February 9). Sierra Club Policy on Transit-Oriented Development. Retrieved from the Sierra Club website https://www.sierraclub.org/press-releases/2018/02/sierraclub-policy-transit-oriented-development, accessed March 8, 2020.

Statistics Canada. (n.d.). Community Highlights for Toronto Division. 2001 Census. Accessed from the Statistics Canada website https://www12.statcan.gc.ca/english/Profilo1/CPo1/Details/Page.cfm?Lang=E\&Geo1=CD\& Code $1=3520 \& G e 02=$ PR\&Code $2=35 \&$ Data $=$ Count $\&$ SearchText $=$ toronto\&SearchType $=$ Begin $\mathrm{s} \&$ SearchPR=01\&B1=All\&Custom=, accessed February 2, 2020.

Statistics Canada. (2007). Toronto, Ontario (Code3520005) (table). 2006 Community Profiles. 2006 Census. Statistics Canada Catalogue no. 92-591-XWE. Ottawa. Released March 13, 2007. Retrieved from the Statistics Canada website https://www12.statcan.gc.ca/censusrecensement/2006/dp-pd/prof/92-591/index.cfm?Lang=E, accessed February 2, 2020.

Statistics Canada. (2012). Toronto, Ontario (Code 3520005) and Canada (Code 01) (table). Census Profile. 2011 Census. Statistics Canada Catalogue no. 98-316-XWE. Ottawa. Released October 24, 2012. Retrieved from the Statistics Canada website http://www12.statcan.gc.ca/census-recensement/2011/dp-pd/prof/index.cfm?Lang=E, accessed February 2, 2020.

Statistics Canada. (2017). Toronto [Census metropolitan area], Ontario and Toronto, C [Census subdivision], Ontario (table). Census Profile. 2016 Census. Statistics Canada Catalogue no. 98-316-X2016001. Ottawa. Released November 29, 2017. Retrieved from Statistics Canada website https://www12.statcan.gc.ca/census-recensement/2016/dppd/prof/index.cfm?Lang=E, accessed February 2, 2020.

Taylor, Mac. (2015, March 17). California's High Housing Costs: Causes and Consequences. Retrieved from the California Legislative Analyst's Office, https://lao.ca.gov/reports/2015/finance/housing-costs/housing-costs.pdf, accessed March $1,2020$. 
Terner Center. (2020, January 17). Key Remaining Questions Following New Amendments to SB 50. Retrieved for the Terner Center for Housing Innovation, UC Berkeley website https://ternercenter.berkeley.edu/blog/2020-amendments-sb-50, accessed March 8, 2020.

Toronto. (2019, July 16). Expanding Housing Options in Toronto- Tackling the Missing Middle and the 'Yellowbelt'. Item MM9.36. Accessed from City of Toronto website: http://app.toronto.ca/tmmis/viewAgendaItemHistory.do?item=2019.MM9.36, September 29, 2019.

Toronto Regional Real Estate Board [TRREB]. (2018). The Majority of GTA Residents Agree that More Construction of New Homes will Help Housing Affordability, just not in their Backyards, a Home Building Industry and REALTORS® Joint Ipsos Poll Finds. Retrieved from the globalnewswire.com website, https://www.globenewswire.com/newsrelease/2018/09/18/1572209/o/en/The-Majority-of-GTA-Residents-Agree-that-MoreConstruction-of-New-Homes-will-Help-Housing-Affordability-just-not-in-their-Backyardsa-Home-Building-Industry-and-REALTORS-Joint-Ipso.html, accessed March 14, 2020.

van Nus, Walter. (1979). "Towards the City Efficient: The Theory and Practice of Zoning 19191930.” In Alan F.J Artibise and Gilbert A. Stelter (Eds.), The Useable Urban Past: Planning and Politics in the Modern Canadian City (pp. 226-246). Macmillan of Canada.

Vancouver. (n.d.). Norquay Village Neighbourhood Centre Plan 2010. Retrieved from the City of Vancouver website https://vancouver.ca/home-property-development/norquay-villageneighbourhood-centre-plan.aspx, accessed March 12, 2020.

Vancouver. (2010). Norquay Village Neighbourhood Centre Plan. Retrieved from the City of City of Vancouver website https://vancouver.ca/docs/planning/norquay-community-plan2010.pdf, accessed March 12, 2020.

City of Vancouver. (2017). Norquay Village Neighbourhood Centre Plan 2010 Progress Update February 2017. Retrieved from the City of Vancouver website https://vancouver.ca/files/cov/norquay-village-progress-bulletin-2017-02.pdf, accessed March 12, 2020.

Wegmann, Jake. (2020). Death to Single-Family Zoning...and New Life to the Missing Middle. Journal of the American Planning Association. 86(1): 113-119.

Weiner, Scott and Daniel Kammen. (2019, March 25). Why Housing Policy is Climate Policy. New York Times. Retrieved from https://www.nytimes.com/2019/03/25/opinion/californiahome-prices-climate.html, accessed March 4, 2020.

White, Richard. (2019). "The Genesis of the Yellowbelt." In House Divided: How the Missing Middle Will Solve Toronto's Housing Crisis,” edited by John Lorinc, Alex Bozikovic, Cheryll Case, and Annabel Vaughan. Pages 30-34. Toronto, ON: Coach House Books. 